\title{
Nonvolcanic Carbon Dioxide Emission at Continental Rifts: The Bublak Mofette Area, Western Eger Rift, Czech Republic
}

\author{
Horst Kämpf $\mathbb{D}^{1},{ }^{1}$ Alena Sophie Broge $\mathbb{D}^{2},{ }^{2}$ Pouria Marzban $\mathbb{D}^{3},{ }^{3}$ Masoud Allahbakhshi $\mathbb{D},{ }^{3}$ \\ and Tobias Nickschick $\mathbb{i}^{4}$ \\ ${ }^{1}$ GFZ German Research Centre for Geosciences, Section Organic Geochemistry, Telegrafenberg, 14473 Potsdam, Germany \\ ${ }^{2}$ Geoscience Centre, Georg-August Universität Göttingen, 37077 Göttingen, Goldschmidtstrasse 3, Germany \\ ${ }^{3}$ GFZ German Research Centre for Geosciences, Section Physics of Earthquakes and Volcanoes, Telegrafenberg, \\ 14473 Potsdam, Germany \\ ${ }^{4}$ Institute of Geophysics and Geology, Talstrasse 35, 04103 Leipzig, Germany
}

Correspondence should be addressed to Horst Kämpf; kaempf@gfz-potsdam.de

Received 14 March 2019; Accepted 2 May 2019; Published 30 October 2019

Guest Editor: Andrzej Solecki

Copyright (C) 2019 Horst Kämpf et al. This is an open access article distributed under the Creative Commons Attribution License, which permits unrestricted use, distribution, and reproduction in any medium, provided the original work is properly cited.

\begin{abstract}
This study presents the results of gas flux measurements of cold, mantle-derived $\mathrm{CO}_{2}$ release at the Bublák mofette field (BMF), located inside of the N-S directed Poćátky Plesná fault zone (PPFZ). The PPFZ is presently seismically active, located in the eastern part of the Cheb Basin, western Eger Rift, Central Europe. The goal of the work was to identify the linkage between tectonics and gas flux. The investigated area has a size of $0,43 \mathrm{~km}^{2}$ in which 1.115 locations have been measured. Besides classical soil $\mathrm{CO}_{2}$ gas flux measurements using the closed chamber method (West Systems), drone-based orthophotos were used in combination with knowledge of plant zonation to find zones of high degassing in the agriculturally unused part of the BMF. The highest observed soil $\mathrm{CO}_{2}$ gas flux is $177.926,17 \mathrm{~g} \mathrm{~m}^{-2} \mathrm{~d}^{-1}$, and the lowest is $0,28 \mathrm{~g} \mathrm{~m}^{-2} \mathrm{~d}^{-1}$. Three statistical methods were used for the calculation of the gas flux: arithmetic mean, kriging, and trans-Gaussian kriging. The average $\mathrm{CO}_{2}$ soil degassing of the $\mathrm{BMF}$ is $30 \mathrm{t} \mathrm{d}^{-1}$ for an area of $0,43 \mathrm{~km}^{2}$. Since the $\mathrm{CO}_{2}$ soil degassing of the Hartoušov mofette field (HMF) amounts to $23 \mathrm{td}^{-1}$ for an area of $0,35 \mathrm{~km}^{2}$, the average dry degassing values of the BMF and HMF are in the same magnitude of order. The amount of $\mathrm{CO}_{2}$ flux from wet mofettes is $3 \mathrm{td}^{-1}$ for the BMF and $0,6 \mathrm{td}^{-1}$ for the HMF. It was found that the degassing in the BMF and HMF is not in accordance with the pull-apart basin interpretation, based on the direction of degassing as well as topography and sediment fill of the suggested basins. En-echelon faults inside of the PPFZ act as fluid channels to depth $\left(\mathrm{CO}_{2}\right.$ conduits). These structures inside the PPFZ show beginning faulting and act as tectonic control of $\mathrm{CO}_{2}$ degassing.
\end{abstract}

\section{Introduction}

The quantification of mass flow between deep reservoirs and the surface is important for understanding deep carbon fluxes, changes of rock and soil atmosphere, influence on biosphere, and connections to atmosphere. Here, we use highresolution measurement of carbon dioxide flux at the surface to characterize nonvolcanic magmatic volatile systems in the Cheb Basin (CB), western Eger (Ohře) Rift (ER), Czech Republic.

The Cenozoic CB lies in the western part of the Bohemian Massif, Central Europe, and is a structural domain of the ER, a $300 \mathrm{~km}$ long, ENE-WSW striking element of the European Cenozoic Rift System (ECRIS) [1, 2]. The basingeometry influenced by the intersection of three regional fault zones, the N-S striking Regensburg-Leipzig-Rostock zone (RLRZ), the NW-SE to NNW-SSE striking ChebDomazlice Graben, and the ENE-WSW faults of the Eger (Ohře) Graben, Figure 1. The Cheb-Domazlice Graben is controlled at the eastern flank by the Mariánské Lázně fault zone (MLFZ) and the Tachov fault zone (TFZ) at the western flank (Figure 1).

The MLFZ, dipping to SW, is approximately $100 \mathrm{~km}$ long morphologically depicted by a $200 \mathrm{~m}$ high escarpment at the 


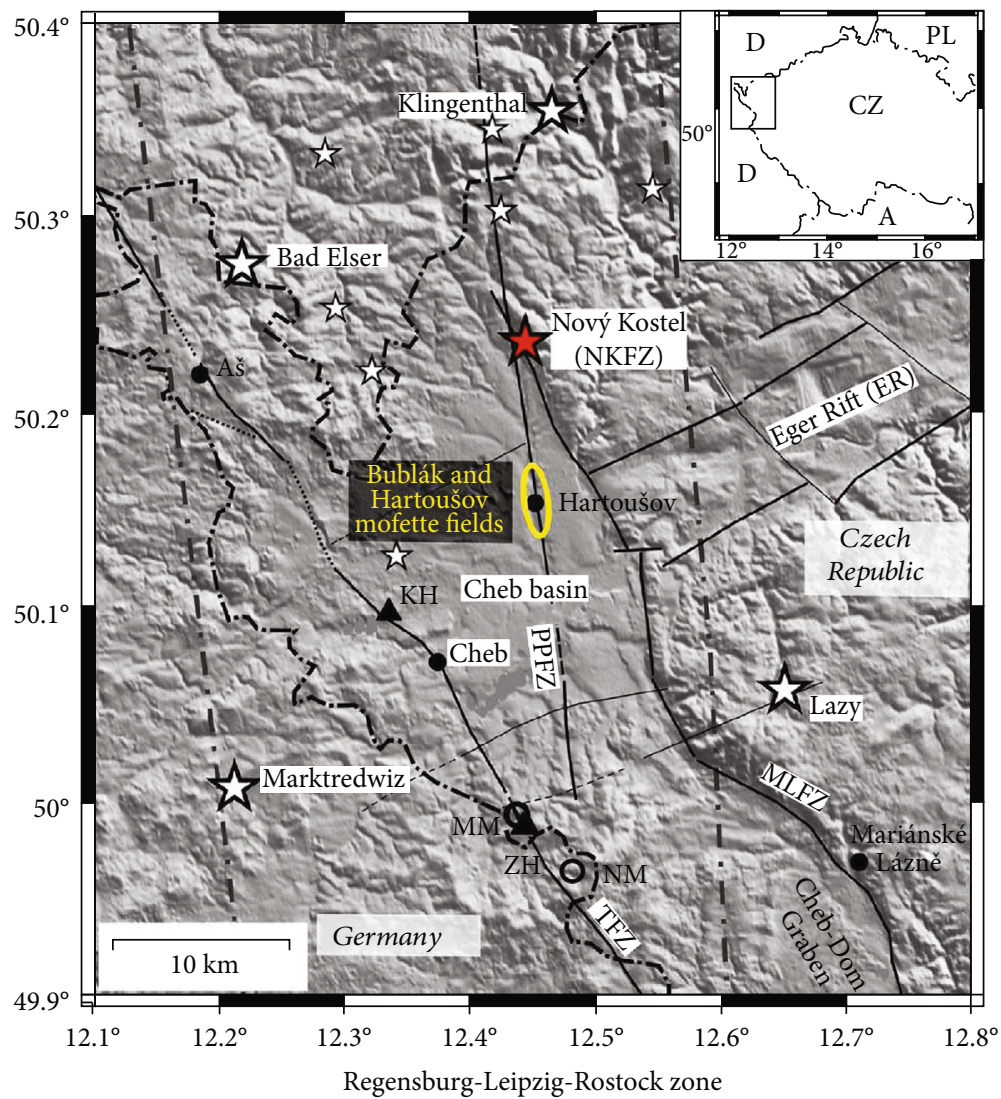

FIgURe 1: Fault zones in the Cheb Basin with Pleistocene scoria cones Železná hůrka (ZH) and Komorní hůrka (KH) (black triangles); black circles mark Mýtina maar (MM) and Neualbenreuth maar (NM); PPFZ Počátky Plesná fault zone, MLFZ Mariánské Lázně fault zone, TFZ Tachov fault zone; white stars point to further locations of swarm earthquake epicentral areas; the red star marks the NKFZ Nový Kostel focal zone $[13,28,35]$.

eastern border of the CB [3]. The western flank of the basin is topographically indistinct, influenced by erosional activity [4] and bordered by the similarly NW-SE striking Tachov fault zone. In the north of the basin are the Ore Mountains (Erzgebirge) and in the south the Kaiserwald/Slavkovský les (Kaiserwald). Cenozoic fluvial and lacustrine sediments with a thickness of up to $300 \mathrm{~m}$ along the MLFZ fill the basin [4].

West Bohemia and the Vogtland on the German side of the border are known for their "earthquake swarms" (German: "Schwarmbeben"), a term first mentioned by Credner [5] that describes earthquakes of low magnitude but high frequency. Earthquake swarms occur mainly in areas of enhanced crustal fluid activity with Quaternary volcanism [6]. These earthquake swarms, combined with evidence for currently ongoing hidden magmatic processes in the subcontinental lithospheric mantle and mantle-derived $\mathrm{CO}_{2}$ degassing at the surface in mineral springs and mofettes, make Cheb Basin to a unique area in Europe $[7,8]$ and one of the best studied nonvolcanic intracontinental rift areas worldwide [9-11].

The youngest volcanic activity in the Cheb Basin is related to the scoria cones Komorní hůrka and Železná hůrka from 0,7 to $0,3 \mathrm{Ma}$ and the two maar diatreme volcanoes of Mýtina and Neualbenreuth that were discovered in 2007 [12] and 2015 [13] (Figure 1).
Within the last 40 years, three swarms that exceeded magnitudes of 4 (1985/86, 2014, and 2018) were observed, with about $90 \%$ of the total seismic moment being released in the Nový Kostel focal zone (NKFZ) [14]. The NKFZ is located close to the intersection of the Počátky Plesná fault zone (PPFZ) and the MLFZ (Figure 1). The significance of the PPFZ as a seismically active fault zone was detected by Bankwitz et al. [15]. Through stress analysis of an earthquake swarm in 2008, Vavryčuk [16] found that the PPFZ is a sinistral fault with a direction of $\approx 169^{\circ}$. The triggering mechanisms for the earthquake swarms in West Bohemia are assumed to be fluids that rise up through the fault zones [6, $7,17]$. On the base of large-scale electrical resistivity tomography and gravity/GPS, data along an E-W striking profile crossing the PPFZ and MLFZ Nickschick et al. [18] mapped the crustal section of the eastern CB up to the depths of more than $1000 \mathrm{~m}$. They proposed a conceptual model in which certain lithological layers (Cenozoic Vildstejn, Cypris, and Main Seam formation) act as caps for the ascending fluids. They hypothesize that any ascending fluid forced along impregnable and impermeable layers, and can only ascent along fractures at the PPFZ and MLFZ.

Aside from the Cheb Basin, $\mathrm{CO}_{2}$-dominated degassing occurs at two more degassing centers: Mariánské Lázně and Karlovy Vary [19-22]. These three resemble each other in 
that all gases are $\mathrm{CO}_{2}$-rich $\left(>99\right.$ vol\% $\mathrm{CO}_{2}$ ) with high $\mathrm{CO}_{2}$ flow and the same level of $\delta^{13} \mathrm{C}$ values, but different levels of ${ }^{3} \mathrm{He} /{ }^{4} \mathrm{He}$ ratios $[8,19]$. On the surface, this causes various degassing phenomena such as more than 100 mineral springs in Fratiškovy Lázně, Mariánské Lázně, and Karlovy Vary; Bad Brambach, Bad Elster, and Sybillenbad and surroundings; and mofettes in Soos, Hartoušov, and Bublák and north of Mariánské Lázně $[17,23]$. The Cheb Basin is particularly interesting because of its high $R_{\mathrm{a}}$ values between 3,6 and 5,9 $R_{\mathrm{a}} \quad\left(R_{\mathrm{a}}=\right.$ measured air-corrected $\mathrm{He}$ isotope ratios were divided by the ${ }^{3} \mathrm{He} /{ }^{4} \mathrm{He}$ of air $\left[{ }^{3} \mathrm{He} /{ }^{4} \mathrm{He}\right.$ air $\left.\left.=1,384 \times 10^{-6}\right]\right)$ points to almost undisturbed degassing from the lithospheric mantle $[8,17,19-21]$. In the Cheb Basin, the mineral springs escape along the WSW-ENE striking faults of the Eger Graben [23]. The mofettes themselves in Hartoušov and Bublák and north of Mariánské Lázně strike N-S and NW-SE $[17,23]$.

\section{Research Area}

The Bublák mofette field (BMF) is located in the Cheb Basin between Hartoušov and Milhostov (Figure 1). It is roughly $1000 \mathrm{~m}$ in length and $500 \mathrm{~m}$ wide. The Plesná river runs through the area and forms a valley, where wet and dry mofettes-cold emission spots of $\mathrm{CO}_{2}$-are present. The thickness of Neogene sediments in the HMF (mudstones, sandstones, and lignite coals, deposited in a lacustrine environment) amounts to $\sim 90 \mathrm{~m}$ [24]. The crystalline basement up to the final depth of the pilot hole HJB-1 consists of altered or/and weathered Palaeozoic mica schists.

Wet mofettes are pools of groundwater in which $\mathrm{CO}_{2}$ rises to the surface, hereby leading to the bubbling sound the area was named after (see [17], supplementary data). Subsurface transport of carbon dioxide is often accompanied by gas bubble collapses that act as noise sources and produce seismic signals. Flores Estrella et al. [25] locate noise sources with seismological investigations. Results suggest the presence of fluid channels to a depth of at least $30 \mathrm{~m}$. The gases consist mainly of $\mathrm{CO}_{2}(>99 \%)$, with traces of $\mathrm{N}_{2}, \mathrm{O}_{2}, \mathrm{Ar}$, $\mathrm{CH}_{4}, \mathrm{He}$, and $\mathrm{H}_{2}[26,27]$. Helium ratios were used as an indicator for the origin of the gas. As ${ }^{3} \mathrm{He}$ related to the mantle, a high $\mathrm{R}_{\mathrm{a}}\left({ }^{3} \mathrm{He} /{ }^{4} \mathrm{He}\right)$ value points to a mantle origin. The high ${ }^{3} \mathrm{He} /{ }^{4} \mathrm{He}$ ratios at Bublák of $\sim 5,9 \mathrm{Ra}$ strongly indicate a subcontinental (lithospheric) mantle origin $(6,32 \pm 0,39$ $\mathrm{Ra}$ ), which is supported by $\delta^{13} \mathrm{C}_{\mathrm{CO} 2}$ from $-1,9$ up to $-4,2 \%$, higher than MORB (mid-ocean ridge basalt, [7, 19]). During an observation period between March and May 2006, an increase in the ${ }^{3} \mathrm{He} /{ }^{4} \mathrm{He}$ ratio from 5,9 up to 6,3 Ra at Bublák was observed [26] and interpreted as a hidden intrusion of magmatic material from a deeper source of the lithospheric mantle.

Dry mofettes, on which this work will focus, are visible at the surface in a change of the vegetation that occurs together with high degassing rates in the proximity of small vents $(<0,2 \mathrm{~m}$ diameter $)$ [28]. This is expressed in crippled vegetation that is less high and brown-colored because of chlorosis, meaning the insufficient production of chlorophyll. Different plant species in the surrounding areas are also found in the dry mofette areas $[29,30]$. Sometimes, the dry mofettes have vegetation-free depressions where soil $\mathrm{CO}_{2}$ concentration and $\mathrm{CO}_{2}$ flux are too high for plants to grow [29]. Because the ground in these areas is saturated with $\mathrm{CO}_{2}$ [28], the organic material does not decompose as fast as in the surrounding areas and accumulates, which leads to an elevated ground level. No molehills exist in the $\mathrm{CO}_{2}$ mofette areas and corpses of bugs and larger animals found around spots of high degassing [31]. For bugs, these act as natural pitfall traps [30].

Plants in $\mathrm{CO}_{2}$ mofette fields are grouped into three categories: mofettophobic plants "that strictly avoid geogenic soil $\mathrm{CO}_{2}$ at concentrations above 2-3\%, whereas those that grow directly above strong $\mathrm{CO}_{2}$ emanations are mofettophilic. Plants, that occur in degassing as well as in control areas are named mofettovague" [31, 32]. Sassmanshausen 2010 carried out measurements in the Bublák area in which he related the different plants to $\mathrm{CO}_{2}$ concentration in different depths in the ground. As seen in [17], the mofettophilic plants consist of low, green, and brown grasses and mofettovague plants in this area are tall, brown grasses.

As the ascent of gases mostly depends on the existence of paths of higher permeability, it is possible to map out these fault zones by means of the gas flow distribution on the surface [23]. In [28], the gas flux was mapped in the Hartoušov mofette field (HMF) about a kilometer south of Bublák. They interpreted the degassing patterns they found as a pullapart basin-like structure and suggested that the BMF is located in a different pull-apart basin, because of the difference in He-isotope trend and sediment fill ([28], Figure 10, inset).

A pull-apart basin consists of two parallel master strike-slip fault segments the so-called principal displacement zones and the oblique-extensional basin sidewall faults with an angle between them that is usually $30-35^{\circ}$. The proportion of length to width is usually $3: 1$, and they are shown as depressional structures [33]. According to Yuce et al. [34], who analyzed degassing in the Amik Basin (SE-Turkey), leakage occurs mainly at the basin sidewall faults.

The goal of this work is to check the pull-apart hypothesis proposed by [28] by mapping the $\mathrm{CO}_{2}$ gas flux in the BMF and to compare it with the results from the HMF. During the course of the measurement, strategy was adjusted to the $\mathrm{BMF}$ and further developed.

\section{Field Locations and Methods}

3.1. Measurement Strategy and Field Locations. The measurements in this work were carried out during two periods in 2017 (August-September) and 2018 (August-October). The region (Bublák and Milhostov areas) is located about one kilometer north of the Hartoušov area, where Kämpf et al. [17] and Nickschick et al. [28] carried out their studies.

As shown in Nickschick et al. [28], an evenly spaced net of measurements is not reliable for dry mofette degassing areas like the Bublák and Milhostov areas because the 


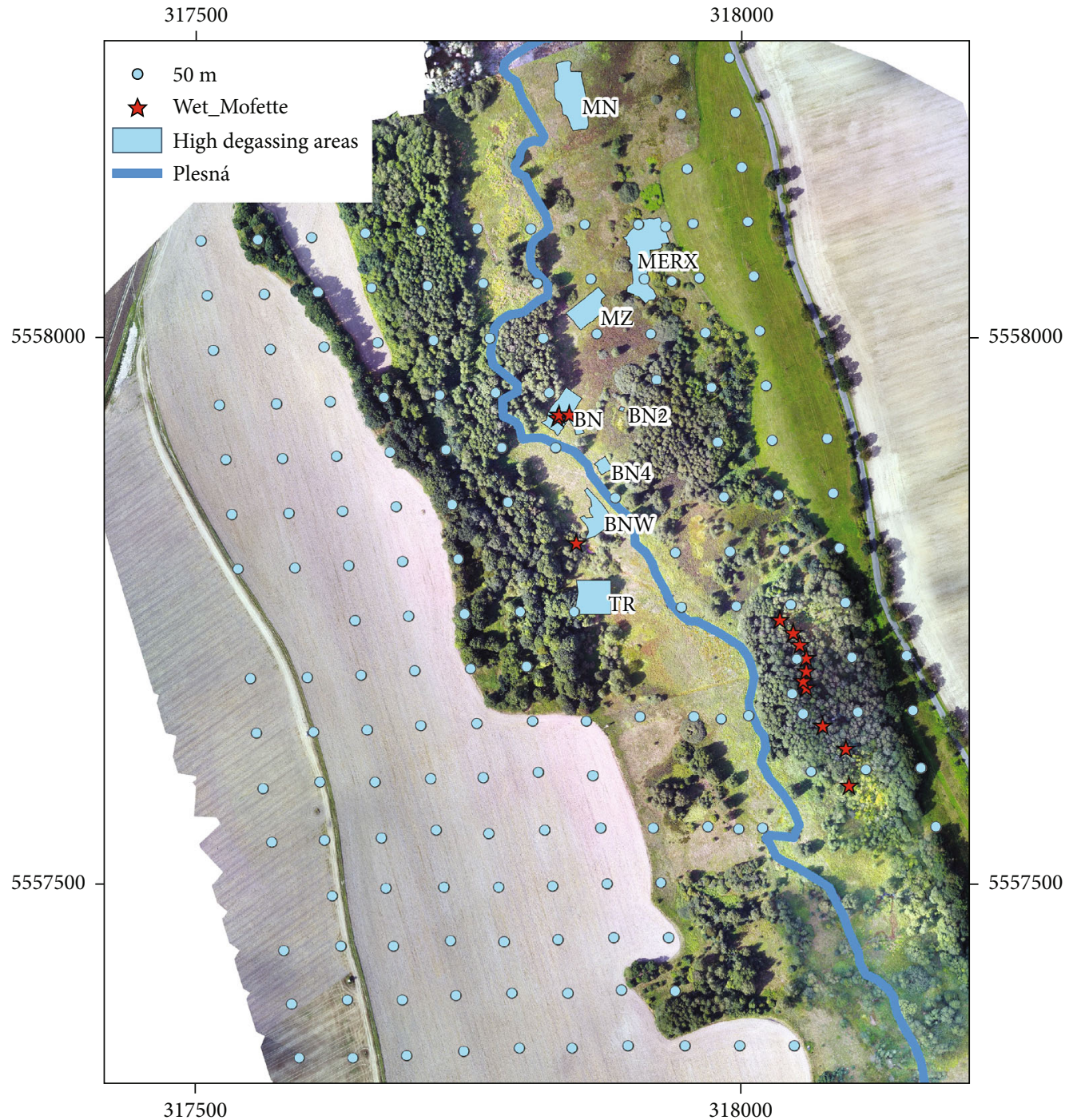

Figure 2: Overview of the Bublák and Milhostov areas. MERX: Milhostov East; MZ: Milhostov Central; MN: Milhostov North; BN: Bublák North; BN2: Bublák North 2; BN4: Bublák North 4; BNW: Bublák North-West; TR: trees.

amount of $\mathrm{CO}_{2}$ discharged by single vents can be over- or underestimated if the sampling position is shifted only by a few decimeters [28]. They advise to use a measurement grid that decreases the distance between the points towards the high degassing zones, followed by proper data analysis. They used $20 \mathrm{~m} \times 20 \mathrm{~m}$ as the biggest distance for a grid. In a smaller area of the same region, Kämpf et al. [17] used a measurement grid with $10 \mathrm{~m} \times 10 \mathrm{~m}$ as the highest distance, also decreasing towards the high degassing zones.

Following the methodology of Kämpf et al. [17] and Nickschick et al. [28] on the one side and being restricted by the time at disposal on the other side, it was decided to start with a measurement grid of $50 \mathrm{~m} \times 50 \mathrm{~m}$ in 2017. This large point spacing for the big grid was chosen to detect high degassing areas and to quantify the background degassing while leaving enough time for accurate measurements. The areas where a high-density grid was placed were shown as brown color in the drone images. This was only possible because, as opposed to Hartoušov, the river valley of the
Bublák area is left in its natural state and not agriculturally used.

While the whole Bublák area is about $415.761 \mathrm{~m}^{2}$ wide, the resulting eight smaller high degassing areas (Figure 2) are about $6.301 \mathrm{~m}^{2}$ wide, amounting to $1,5 \%$ of the whole area (Table 1). This made it possible to focus on the high degassing zones with accurate measurements.

In 2018 (August-October), the high degassing areas were measured with a smaller spacing that was $2,5 \mathrm{~m} \times 2,5 \mathrm{~m}$ in the degassing center and $5 \mathrm{~m} \times 5 \mathrm{~m}$ or $10 \mathrm{~m} \times 10 \mathrm{~m}$ in the periphery. Some points were impossible to be measured as their locations were too wet or overgrown. Overall, 1.122 points were put, of which 1.115 were measured, each point once.

3.2. Gas Flux Measurements and Meteorological Conditions. To quantify the rate of discharge at the surface, a portable diffuse flux meter made by West Systems (Italy, closed-chamber method) was used. The device includes both a LI-COR LI$820 \mathrm{CO}_{2}$ detector (Table 2) and a WS-HC $\mathrm{CH}_{4}$ detector, 
TABLE 1: Measurement parameters of the areas.

\begin{tabular}{|c|c|c|c|c|c|}
\hline Year & Area name & Abbreviation & Measured area $\left(\mathrm{m}^{2}\right)$ & $\begin{array}{l}\text { Ratio of measured } \\
\text { area to total area }(\%)\end{array}$ & Number of measured points \\
\hline \multicolumn{6}{|c|}{$50 \mathrm{~m}$ grid } \\
\hline 2017 & $50 \mathrm{~m}$ & $50 \mathrm{~m}$ & 432.358 & $100 \%$ & 179 \\
\hline \multicolumn{6}{|c|}{ Detected areas with high degassing } \\
\hline & Milhostov East & MERX & 1.685 & $0,39 \%$ & 349 \\
\hline & Milhostov Central & $\mathrm{MZ}$ & 703 & $0,16 \%$ & 132 \\
\hline & Milhostov North & $\mathrm{MN}$ & 1.337 & $0,31 \%$ & 159 \\
\hline & Bublák North & $\mathrm{BN}$ & 816 & $0,19 \%$ & 127 \\
\hline \multirow[t]{5}{*}{2018} & Bublák North 2 & BN2 & 18 & $0,00 \%$ & 8 \\
\hline & Bublák North 4 & BN4 & 145 & $0,03 \%$ & 23 \\
\hline & Bublák North-West & BNW & 612 & $0,14 \%$ & 71 \\
\hline & Trees & $\mathrm{TR}$ & 985 & $0,23 \%$ & 67 \\
\hline & Total & & 6.301 & $1,46 \%$ & 936 \\
\hline 2017 & & & 432.358 & & 1.115 \\
\hline
\end{tabular}

TABLe 2: Technical data LICOR LI-820 (LI-COR, uncertainty and upper limit from [28] and the manufacturer's manual).

\begin{tabular}{|c|c|c|c|c|}
\hline $\begin{array}{l}\text { LI-COR LI- } 820 \\
\text { Measurement range }\end{array}$ & $0-20000 \mathrm{ppm}$ & & & \\
\hline Accuracy & $3 \%$ of measurement & Calibration drift: & Zero drift & $<0,15 \mathrm{ppm} /{ }^{\circ} \mathrm{C}$ \\
\hline Measurement principle & Nondispersive infrared & & Span drift & $<0,03 \% /{ }^{\circ} \mathrm{C}$ \\
\hline Uncertainty & $4 \%$ (increases with flux as the chamber is saturated faster) & Upper limit & \multicolumn{2}{|c|}{$\begin{array}{l}\mathrm{Up} \text { to } 600 \mathrm{~mol} \mathrm{~m}^{-2} \mathrm{~d}^{-1} \\
\text { accurately measurable }\end{array}$} \\
\hline
\end{tabular}

although the $\mathrm{CH}_{4}$ detector was not used because the methane concentration of the Bublák mofette amounts to 2,5 ppm only [27] and is overshadowed by the sheer amount of emitted carbon dioxide.

Some of the fluxes were too high to be measured with high accuracy as the chamber filled in just a few seconds and some values were much larger than the accuracy limit of $600 \mathrm{~mol} \mathrm{~m}^{-2} \mathrm{~d}^{-1}$ and $26.406 \mathrm{~g} \mathrm{~m}^{-2} \mathrm{~d}^{-1}$, respectively. Nickschick et al. [28] already encountered this problem. To get a better accuracy for the data, they took multiple measurements in this case, as the chamber fills too fast and can only be estimated by repeated measurements.

Calibration of the sensor is only seldom needed and done by an expert. As such, no calibrations must be done during measurement of in the field. To calculate the gas flux, air temperature and barometric pressure also must be measured in the field. Using these, an accumulation chamber factor $K$ is calculated which is multiplied with the value measured in the field in $\mathrm{ppm} \mathrm{s}^{-1}$ to obtain the gas flux in mol m $\mathrm{m}^{-2} \mathrm{~d}^{-1}$. The calculation for $K$ is done with the following formula (West [36]):

$$
K=\frac{86400 * P}{10^{6} * R * T_{k}} * \frac{V}{A},
$$

where $K$ is the accumulation chamber factor, $P$ is the barometric pressure in mbar, $R$ is the gas constant 0,08314510 bar L K $^{-1} \mathrm{~mol}^{-1}, T_{k}$ is the air temperature in Kelvin, $V$ is the volume of the accumulation chamber in
TABLE 3: Specifications of the accumulation chambers (West [36]).

\begin{tabular}{ccc} 
& Chamber A & Chamber B \\
\hline$V$ & $2,756^{*} 10^{-3} \mathrm{~m}^{3}$ & $V=6,878^{*} 10^{-3} \mathrm{~m}^{3}$ \\
$A$ & $3,14^{*} 10^{-2} \mathrm{~m}^{2}$ & $A=7,116^{*} 10^{-2} \mathrm{~m}^{2}$ \\
\hline
\end{tabular}

cubic meters, and $A$ is the area of the accumulation chamber in square meters.

The device uses accumulation chambers with different volumes (Table 3) from which the accumulating gas is pumped to the LICOR-Detector. In the accumulation chambers, the gas is mixed by a fan, so that the $\mathrm{CO}_{2}$, which is denser than air, does not form a separate layer. During the measurements, the accumulation chambers A (small) and B (big) were used. While chamber A is better for measuring small fluxes due to its increased sensitivity, chamber $B$ is more accurate at gas fluxes above $1.000 \mathrm{~g} \mathrm{~m}^{-2} \mathrm{~d}^{-1}$ (West [36]).

While performing a measurement, the chosen chamber must be placed as airtight as possible on the ground to prevent an influx of air, especially during windy days [37]. Then, the measurement is started via the software "Fluxmeter" on a handheld computer that is connected to the flux meter by Bluetooth. During measurement, the software shows a curve with time on the $x$-axis and ppm of $\mathrm{CO}_{2}$ or $\mathrm{CH}_{4}$ in the gas in the accumulation chamber on the $y$-axis. The user now must find the best fit to the 


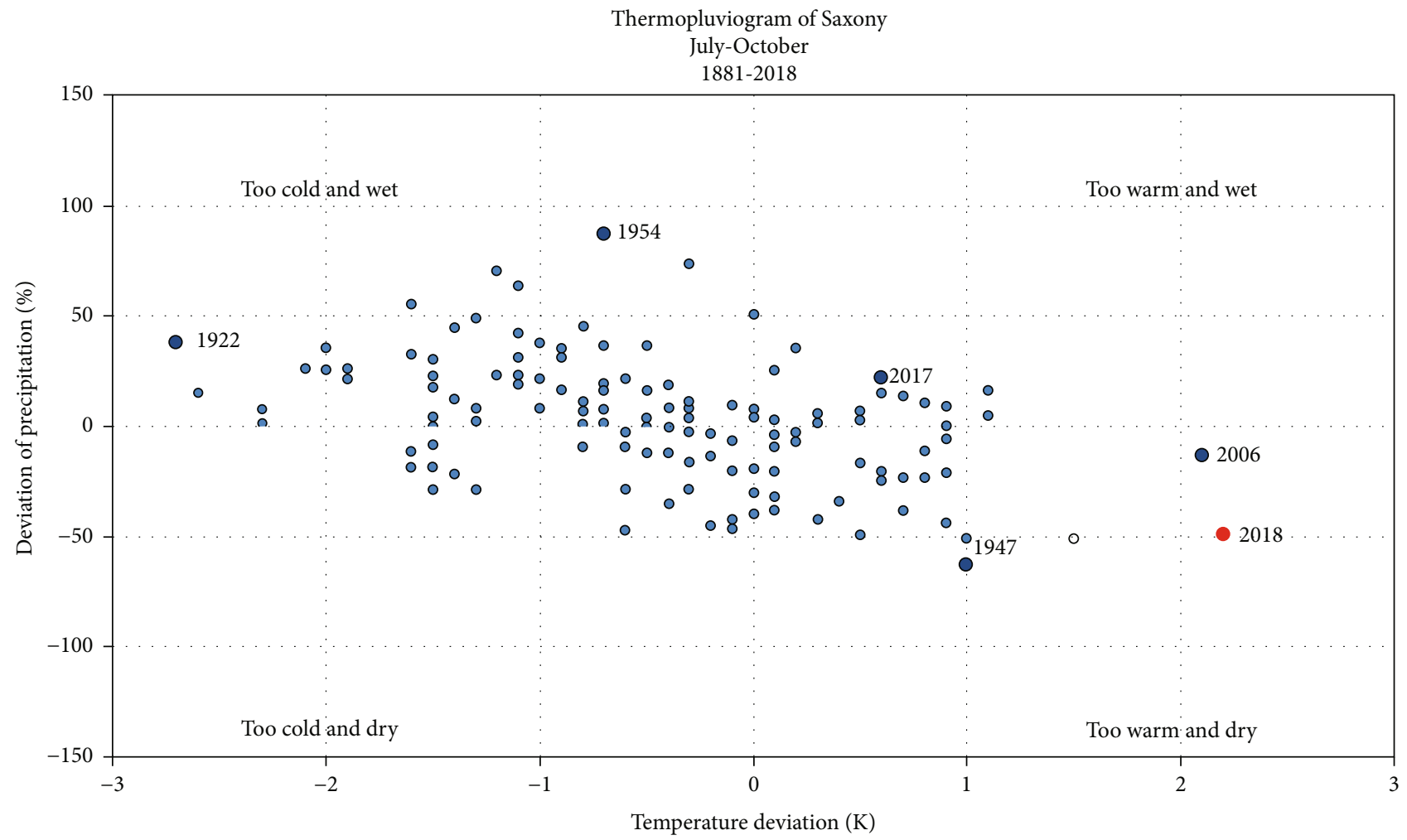

FIGURE 3: Deviation from long-standing average: summer of 2018 as an exceptional summer. Thermopluviogram of the Free State of Saxony, Germany (July-October, 1881-2018); DWD (German Weather Service, personal comm. 17.12.2018).

curve presented on the handheld computer. This method is called the closed chamber method and has been used since 1998, when Chiodini et al. [37] tested it in a volcanic area and found it to be a reliable and quick method.

For measurement, the ground must be dry, as water would show the same signature as $\mathrm{CO}_{2}$ in the infrared LICOR sensor and falsify the measurements or damage the sensor through condensation [37]. To minimize the risk of this, a desiccant was placed between the accumulation chamber and the sensor. Additionally, measurements in dry periods are generally preferred as rain and soil humidity may influence soil-gas concentrations [38]. This is especially the case in an area such as this one where beneath the soil is a layer of clays [39]. To prevent biogenic influence by plants and to guarantee an airtight environment within the chamber as much as possible, a hole of $30 \mathrm{~cm}$ depth was dug before measurements.

As seen in Figure 3, the summer of 2018 in Central Europe including Saxony and working area in the western Eger Rift was exceptional in being the warmest summer and one of the driest summers since 1881 . This led to areas that were swampy in the year before being dry and measurable (e.g., surrounding MZ). It was also possible to measure directly after digging the holes because the ground was dry even in $30 \mathrm{~cm}$ depth. While 2017 still was relatively warm, it was sometimes necessary to let the ground dry for a day or two after digging the hole. This is also reflected in the thermopluviogram below (Figure 3), where the summer of 2018 is the warmest and one of the driest summers on record, while the summer of 2017 was still warm, but not nearly as warm as 2018 and a little wetter than average.

\subsection{GPS Measurements}

3.3.1. Handheld GPS. The points for the $50 \mathrm{~m}$ grid were calculated before measuring. To find the correct coordinates in the field, a handheld Garmin GPSMAP 60CSx was used, as the device showed the coordinates in real time. The handheld GPS was used because even though the error of this device and most handheld GPS is in the range of several meters, in the densely vegetated Plesná area, it is still more accurate and quicker than measuring the distance by hand.

3.3.2. Differential GPS. For the areas of high degassing, a point-to-point distance of $2,5 \mathrm{~m}$ was used because of the high differences in gas flux and tectonic control of degassing over small distances. As the error of the handheld GPS would have been close to-or sometimes even higher than-the distance between the points themselves, a differential GPS (D-GPS) with a higher accuracy than the handheld GPS was used.

The available D-GPS was a $1200+$ by Leica, which uses a reference station that remains stationary during the measurements and a rover antenna which is carried to the data points and collects data for several minutes. As there was a constantly high number of satellites receivable, a single point only took two minutes to measure. Because the D-GPS was only available for two weeks during the second measurement period, measuring all the points would have taken too long. 


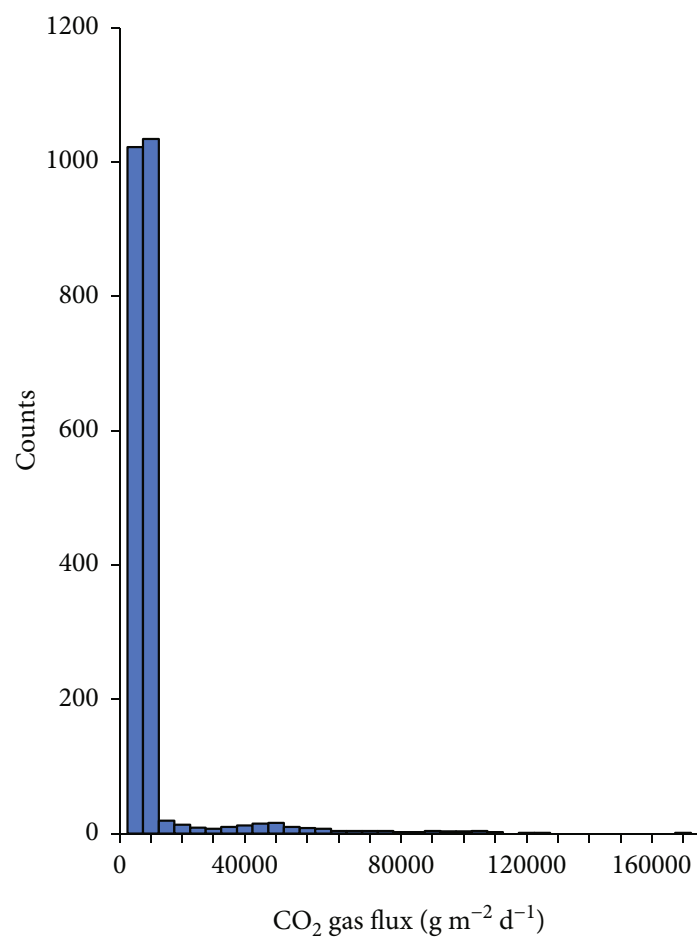

(a)

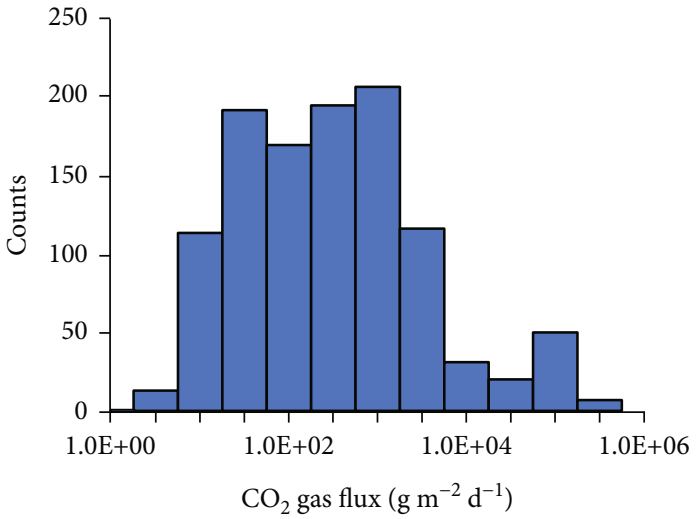

(b)

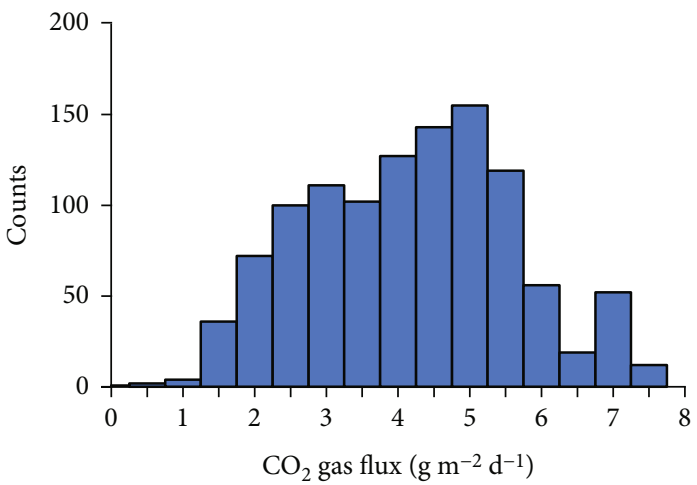

(c)

FIgURE 4: Gas flux in $\mathrm{g} \mathrm{m}^{-2} \mathrm{~d}^{-1}$ : (a) the dataset; (b) displaying the data on a logarithmic scale; and (c) the box-cox transformed dataset with $-0,093$ as lambda.

Therefore, it was decided to take a high-resolution drone image after digging the holes for the measurements, georeference it, and then insert the points in ArcGIS (Figure 2).

3.4. Drones. During the measurements, multiple drone images were taken. At the beginning of the measuring period in August 2017, an image was taken, providing an overview of the area. In October 2018, a high-resolution drone image was taken to reduce the time needed for the GPS measurements.

To obtain the images, DJI Phantom 4 was used. This drone provides the possibility to take $4 \mathrm{~K}$ images and has a flight time of 30 minutes. The drone can either be controlled by the user or follow a preset path and automatically take a picture every second. The resulting pictures were stitched together, creating an orthophoto, using the software Agisoft.

The drones have built-in GPS for orientation and geotagging of the images. To get more accurate images, Ground Control Points (GCPs) can be set, whose coordinates were obtained by using the D-GPS and then used for georeferencing. This method was used for the drone image taken in October 2018, which shows the northern part of the area where most dry mofettes are located.

The drone image from 2017 offers less detail but covers the whole area (Figure 2). It is also less accurate because it did not use GCPs for georeferencing. However, it was useful for identifying degassing structures by their brown color because it was taken in August as opposed to the 2018 image that was taken in October when many of the plants around the mofettes already started changing color.

\subsection{Geostatistical Data Analysis}

3.5.1. Interpolation of Missing Values. To be able to quantify the gas flux for the whole area as accurately as possible, the values need to be interpolated for the unmeasured areas. This was performed using the Software ArcGIS, which provides various geostatistical methods. After the prediction was done, the calculated values were divided into $1 \mathrm{~m}^{2}$ sized cells to obtain the calculated values for each square meter for further calculations.

As the results of this study should be comparable to the results from Nickschick et al. [28], the same methods for data analysis were applied. The used methods were arithmetic mean, ordinary kriging, and trans-Gaussian kriging. An exception to this is the radial basis function, which was not used, as its direct interpolation of the measurement points leads to a severe overestimation of degassing as in Nickschick et al. [28]; the data of this work did not follow a normal/Gaussian distribution (Figure 4(a)), and the standard deviation was very high. 
3.5.2. Arithmetic Mean. Gilbert [40] and Lewicki et al. [41] said that the arithmetic mean can be used to estimate the amount of ejected $\mathrm{CO}_{2}$ if it is normally distributed.

As discussed in [28], the arithmetic mean is not suitable for interpretation due to its high mean and standard deviation that are derived from the skewedness. It is nevertheless the simplest method to calculate an average and overall degassing and might be sensible to use in case no computer with ArcGIS is available and if the person is aware of the errors done by this method.

3.5.3. Ordinary Kriging. Kriging estimates values for locations without measured points. It takes the spatial distribution of the measurement points into consideration but overestimates minima and underestimates maxima [28], (Figure 4(b)). Therefore, the standard deviation will be lower than by using the arithmetic mean, but it will still overrate the actual amount of degassing. The formula for kriging is as follows:

$$
\widehat{Z}\left(s_{0}\right)=\sum_{i=1}^{N} \lambda_{i} Z\left(s_{i}\right)
$$

where $Z\left(s_{i}\right)$ is the measured value at the $i$-th position, $\lambda_{i}$ is the unknown weighting for the measured value at the $i$-th position, $s_{0}$ is the predicted position, and $N$ is the number of measured values [42].

3.5.4. Trans-Gaussian Kriging. For non-Gaussian distributions of the measured values, all standard geostatistical methods will provide an incorrect estimation. Normally, a simple transformation such as a data transformation into a logarithmic scale suffices, but here, the data is heavily skewed even after doing so. For trans-Gaussian kriging, the dataset is transformed by using a power transformation such as the box-cox transformation to make the data as normally distributed as possible (Figure $4(\mathrm{c})$ ) and then interpolated by kriging. Afterwards, the data is transformed back by ArcGIS and can be used for further calculations. The formula for the Box-cox transformation for values of $\lambda$ that are not equal to zero is as follows:

$$
X^{\lambda}=\frac{X^{\lambda}-1}{\lambda},
$$

where $X$ is the measured value and $\lambda$ is the power parameter [43].

The value for $\lambda$ that would best transform the dataset is -0,093. As ArcGIS only allows values for lambda larger or equal to $-0,1$, this value was used instead. Please note that also other ways of data transformation exist (such as the normal score transformation in ArcGIS).

\section{Results}

4.1. Overview of Soil $\mathrm{CO}_{2}$ Survey. The entire investigated area has a size of $432.358 \mathrm{~m}^{2}\left(0,43 \mathrm{~km}^{2}\right)$ in which 1.115 points have been measured (Figure 5). The highest observed gas flux is $177.926,17 \mathrm{~g} \mathrm{~m}^{-2} \mathrm{~d}^{-1}$ close to the center of the MZ area. The lowest measured value is $0,28 \mathrm{~g} \mathrm{~m}^{-2} \mathrm{~d}^{-1}$ and is in the western edge of the $50 \mathrm{~m}$ grid. Overall, higher gas fluxes are observed in the floodplain of the Plesná.

The overall degassing varies by several orders of magnitude by using different methods for calculation and visualizes how improper data analysis leads to severely incorrect estimations. $1.638 \mathrm{t} \mathrm{d}^{-1}$ calculated by using the arithmetic mean as an overall value for the degassing is likely to be a huge overestimation due to the influence of the high skewedness. The true overall degassing per day for the area is likely to be between $30 \mathrm{td}^{-1}$ and $154 \mathrm{td}^{-1}$, calculated by transGaussian kriging and kriging, respectively (Table 4).

As the $\mathrm{CO}_{2}$ is emitted from small vents, high degassing values occur in their proximity [44] which leads to few measured values contributing to most of the measured $\mathrm{CO}_{2}$. In this case, $90 \%$ of the total $\mathrm{CO}_{2}$ are discharged by the top 66 highest values which make out $5,9 \%$ of all data and $99 \%$ by the top $155(13,9 \%)$ values. This again illustrates the high skewedness of the data and the influence of the small degassing channels on the overall degassing.

To estimate the amount of degassing from an external source-in this case from the mantle-the gas fluxes can be divided into three different categories (as seen in [45]). Population A represents the biogenic background degassing with $25 \mathrm{~g} \mathrm{~m}^{-2} \mathrm{~d}^{-1}$, a value that has been suggested by Kämpf et al. [17] based on carbon isotope measurements of soil gas. This value is close to the $27 \mathrm{~g} \mathrm{~m}^{-2} \mathrm{~d}^{-1}$ that were calculated as an average for the $50 \mathrm{~m}$ raster and thus a sensible estimation for the background degassing by plants and soil in this area. Population B represents a zone of mixture between biogenic and endogenic degassing with an upper limit of $100 \mathrm{~g} \mathrm{~m}^{-2} \mathrm{~d}^{-1}$. Every value above this belongs to population $\mathrm{C}$ and indicates endogenous degassing (Table 5).

It can be stated that $56 \%$ of all measured data belong to population $\mathrm{C}$, endogenous. For the surveyed areas, MERX has the highest percentage (77\%) for this population. For every area except for $50 \mathrm{~m}$, population $\mathrm{C}$ has an average degassing two orders of magnitude higher than populations A and B (Table 5). For population C, area BN24 has the highest average with $10.678 \mathrm{~g} \mathrm{~m}^{-2} \mathrm{~d}^{-1}$, making up $62 \%$ of the total measured values in this area. The lowest average of population $\mathrm{C}$ has $50 \mathrm{~m}$ with $336 \mathrm{~g} \mathrm{~m}^{-2} \mathrm{~d}^{-1}$ (3\% of all measured values).

4.2. Surveyed Areas. Figures 6 and 7 show the measurement points for the surveyed areas color-coded by their $\mathrm{CO}_{2}$ soil gas flux. White dots represent population $\mathrm{A}$, and yellow represents population B. Population $\mathrm{C}$ has been split into values above $500 \mathrm{~g} \mathrm{~m}^{-2} \mathrm{~d}^{-1}$ which are shown in red and values between 100 and $500 \mathrm{~g} \mathrm{~m}^{-2} \mathrm{~d}^{-1}$ in green to make the central areas of the mofettes visible.

4.2.1. $50 \mathrm{~m}$. Only $3 \%$ of the values in the $50 \mathrm{~m}$ area belong to population $\mathrm{C}$ as opposed to the average $56 \%$ (Table 5). The highest measured flux is $488,18 \mathrm{~g} \mathrm{~m}^{-2} \mathrm{~d}^{-1}$ in the forest on the eastern side of the Plesná and the smallest $0,28 \mathrm{~g} \mathrm{~m}^{-2} \mathrm{~d}^{-1}$ near the southwestern corner of the grid, which is also the smallest measured value overall.

Figure 5 shows that most degassing, higher than background degassing, is in the Plesná valley and not in the 


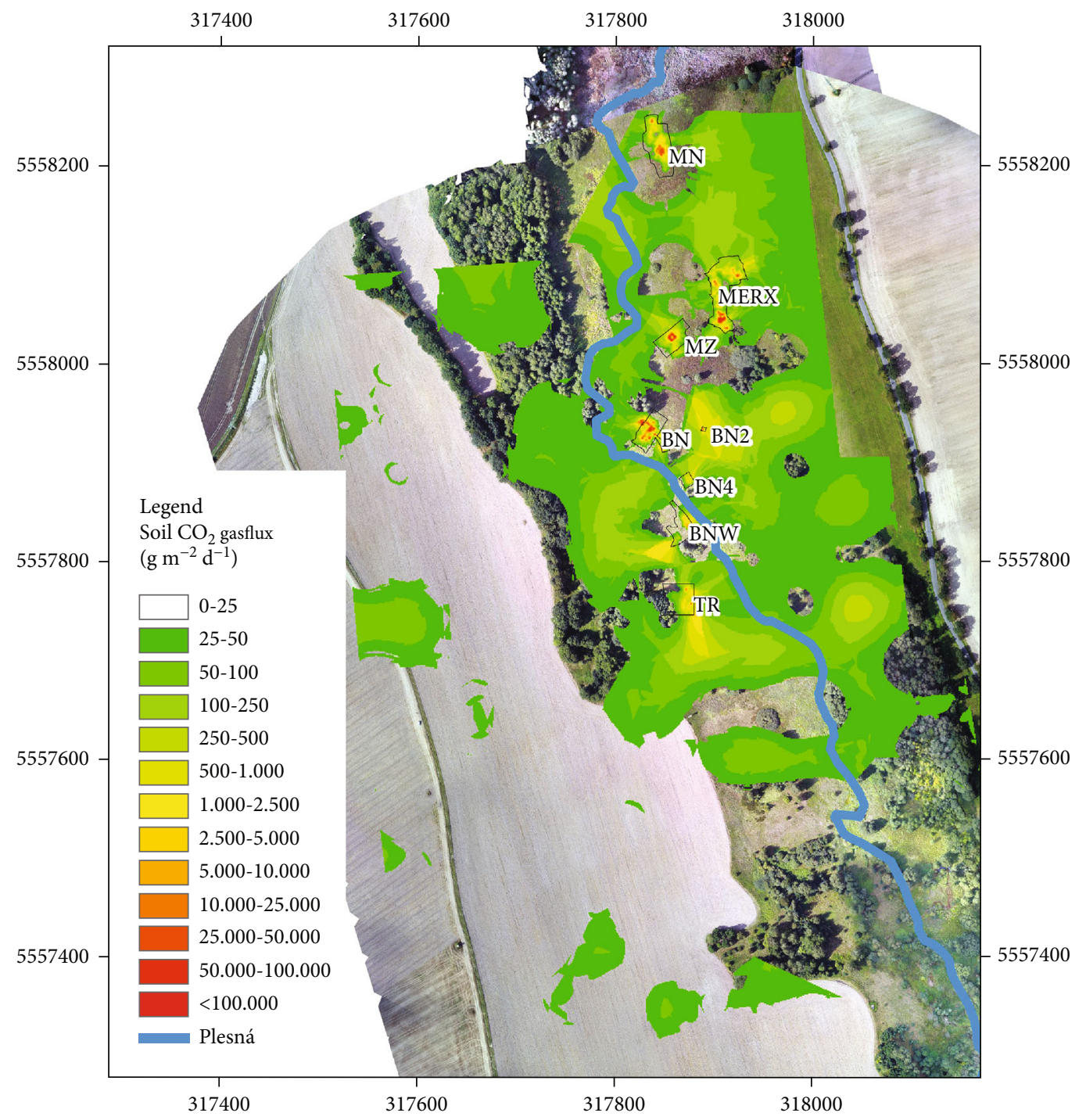

Figure 5: Quantified $\mathrm{CO}_{2}$ soil gas flux for $1 \mathrm{~m}^{2}$ after interpolation of 1.115 measuring points in the Bublák mofette field using trans-Gaussian kriging.

TABLE 4: Averages and totals for the whole area through different methods.

\begin{tabular}{lcc}
\hline Method & Average $\left(\mathrm{g} \mathrm{m}^{-2} \mathrm{~d}^{-1}\right)$ & Overall $\left(\mathrm{t} \mathrm{d}^{-1}\right)$ \\
\hline Arithmetic mean & 3.996 & 1.638 \\
Kriging & 370 & 154 \\
Trans-Gaussian kriging & 73 & 30 \\
\hline
\end{tabular}

agriculturally used fields in the east of the area. An exception to this is the meadow to the west of the valley where there is constantly slightly higher degassing than the background value. The forest where most of the wet mofettes are located has predominantly low degassing values, except for its north, where the highest degassing value of the $50 \mathrm{~m}$ raster was recorded.

4.2.2. Milhostov East (MERX). The Milhostov East area (Figure $6(\mathrm{a})$ ) is the largest area with the most measure- ment points (Table 6). Most of the area is elongated in a $\mathrm{N}-\mathrm{S}$ direction and would be oval shaped if not for the degassing close to the field. It consists of multiple anomalies that are distinguishable from each other in Figure 5, but less in Figure 6(a), as most of the area has endogenous degassing. The areas with brown vegetation show an overlap with areas of endogenous degassing. For example, degassing decreases towards the solitary bush in the upper middle of the degassing area.

MERX is the area with the second-highest maximum degassing $\left(125.773,33 \mathrm{~g} \mathrm{~m}^{-2} \mathrm{~d}^{-1}\right)$. The lowest degassing value is $8,43 \mathrm{~g} \mathrm{~m}^{-2} \mathrm{~d}^{-1} .77 \%$ of the measured values belong to population $\mathrm{C}$.

4.2.3. Milhostov Central (MZ). The Milhostov Central area (Figure 6(b)) consists of a singular, round anomaly that is very well visible in the 2017 drone image and Figure 6. The zone of endogenous degassing is bigger than the zone of brown vegetation, but otherwise very similar in shape and location. 
TABLE 5: Estimated parameters and partitioned populations of the measured data in the surveyed areas.

\begin{tabular}{|c|c|c|c|c|c|c|}
\hline Name & Population & Proportion (\%) & Average gas flux $\left(\mathrm{g} \mathrm{m}^{-2} \mathrm{~d}^{-1}\right)$ & \multicolumn{2}{|c|}{$90 \%$ confidence $\left(\mathrm{g} \mathrm{m}^{-2} \mathrm{~d}^{-1}\right)$} & Overall $\left(\mathrm{t} \mathrm{d}^{-1}\right)$ \\
\hline \multirow{4}{*}{$50 \mathrm{~m}$} & A (background) & 72 & 11,3 & 12,1 & 10,4 & 0,001 \\
\hline & B (background) & 25 & 38,3 & 41,1 & 35,5 & 0,002 \\
\hline & C (endogenous) & 3 & 336,1 & 435,2 & 237,1 & 0,002 \\
\hline & Total & 100 & 27,3 & 34,6 & 20 & 0,005 \\
\hline \multirow{4}{*}{ MERX } & A (background) & 5 & 17,8 & 19,7 & 15,9 & 0,0003 \\
\hline & B (background) & 18 & 63,5 & 68,7 & 58,4 & 0,004 \\
\hline & C (endogenous) & 77 & $6.779,6$ & $8.830,4$ & $4.728,8$ & 1,83 \\
\hline & Total & 100 & $4.911,0$ & $6.413,9$ & $3.408,1$ & 1,83 \\
\hline \multirow{4}{*}{$\mathrm{MZ}$} & A (background) & 20 & 16,8 & 18,6 & 15,1 & 0,0004 \\
\hline & B (background) & 26 & 46,8 & 51,5 & 42,1 & 0,002 \\
\hline & C (endogenous) & 55 & $8.791,3$ & $13.759,8$ & $3.822,7$ & 0,8 \\
\hline & Total & 100 & $6.092,3$ & $9.592,3$ & $2.592,4$ & 0,8 \\
\hline \multirow{4}{*}{ MN } & A (background) & 15 & 9,8 & 11,7 & 7,8 & 0,0002 \\
\hline & B (background) & 19 & 52,1 & 57,9 & 46,2 & 0,002 \\
\hline & C (endogenous) & 66 & $4.643,2$ & $6.299,5$ & $2.986,8$ & 0,56 \\
\hline & Total & 100 & $3.549,3$ & $4.923,5$ & $2.175,0$ & 0,56 \\
\hline \multirow{4}{*}{$\mathrm{BN} 24$} & A (background) & 25 & 10,1 & 11,4 & 8,8 & 0,0004 \\
\hline & B (background) & 13 & 53,7 & 62,7 & 44,7 & 0,001 \\
\hline & C (endogenous) & 62 & $10.677,5$ & $13.630,8$ & $7.724,3$ & 1,05 \\
\hline & Total & 100 & $6.632,1$ & $8.584,8$ & $4.679,4$ & 1,05 \\
\hline \multirow{4}{*}{ BNW } & A (background) & 46 & 6,5 & 7,7 & 5,4 & 0,0002 \\
\hline & B (background) & 19 & 57,3 & 66,4 & 48,2 & 0,001 \\
\hline & C (endogenous) & 36 & $3.082,0$ & $6.021,0$ & 143,1 & 0,08 \\
\hline & Total & 100 & $1.114,4$ & $2.202,9$ & 25,8 & 0,08 \\
\hline \multirow{4}{*}{ TR } & A (background) & 15 & 12,4 & 15,3 & 9,4 & 0,0001 \\
\hline & B (background) & 12 & 57,2 & 69,9 & 44,6 & 0,0005 \\
\hline & C (endogenous) & 73 & $2.222,7$ & $3.962,3$ & 483,1 & 0,11 \\
\hline & Total & 100 & $1.634,3$ & $2.921,4$ & 347,1 & 0,11 \\
\hline \multirow{4}{*}{ Total } & A (background) & 25 & 11,4 & 12,1 & 10,8 & 0,003 \\
\hline & B (background) & 19 & 52,8 & 55,3 & 50,3 & 0,01 \\
\hline & C (endogenous) & 56 & $7.098,0$ & $8.401,7$ & $5.794,3$ & 4,43 \\
\hline & Total & 100 & $3.996,0$ & $4.747,7$ & $3.244,2$ & 4,44 \\
\hline
\end{tabular}

In its center, there are multiple vegetation-free depressions. In one of them, the highest degassing value in all the areas $\left(177.926,17 \mathrm{~g} \mathrm{~m}^{-2} \mathrm{~d}^{-1}\right)$ was found. The lowest degassing value is $6,85 \mathrm{~g} \mathrm{~m}^{-2} \mathrm{~d}^{-1} .55 \%$ of the measured values belong to population C.

4.2.4. Milhostov North (MN). The Milhostov North area (Figure 6(c)) is the northernmost of the measured areas. Like MERX, it is elongated in a roughly N-S direction. It has a large degassing anomaly in the south and a smaller one in the north. The areas with brown vegetation overlap very well with the areas of endogenous degassing.

$66 \%$ of the measured values belong to population $\mathrm{C}$. The highest degassing value is $79.591,73 \mathrm{~g} \mathrm{~m}^{-2} \mathrm{~d}^{-1}$, one of the moderate values for maximum degassing. The lowest value in this area is $2,29 \mathrm{~g} \mathrm{~m}^{-2} \mathrm{~d}^{-1}$ (Table 6).
4.2.5. Bublák North (BN24). As both BN2 and BN4 are small degassing structures, they have been combined with $\mathrm{BN}$ for analytic purposes to form BN24 (Figure 7(a)). BN, the largest of these areas, has wet mofettes that have been measured before in addition to the dry degassing area that surrounds these. One of these wet mofettes has been artificially made by drilling. It might be either a large, circular anomaly or multiple clustered small anomalies as there are some points of midhigh degassing among points of very high degassing. To the south of the area, there is an offshoot of high degassing that is obvious in the drone image due to its brown color.

The Bublák North 2 area is the smallest measured degassing area, with an extent of only $18 \mathrm{~m}^{2}$. It is located about $40 \mathrm{~m}$ to the east of $\mathrm{BN}$ in an area that is otherwise covered with water due to a spring close to the road. This degassing area is elevated and therefore dry and measurable. Nine 

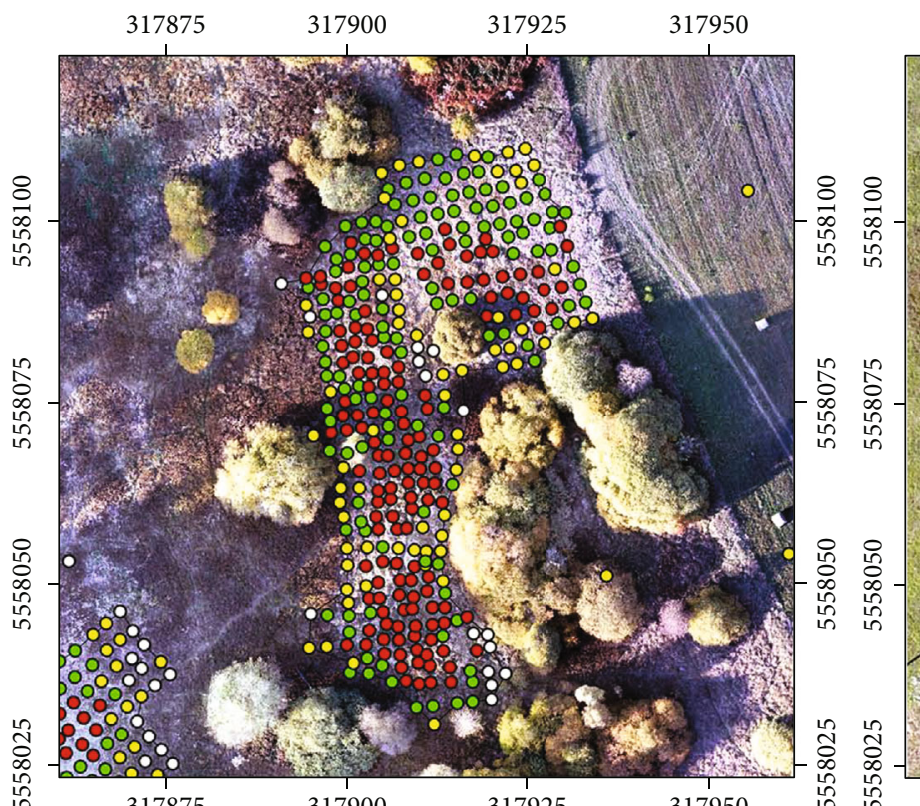

317875

317900

317925

317950

Measurement points

Flux $\left(\mathrm{g} \mathrm{m}^{-2} \mathrm{~d}^{-1}\right)$

O $<25$
○ $25-100$
O $100-500$

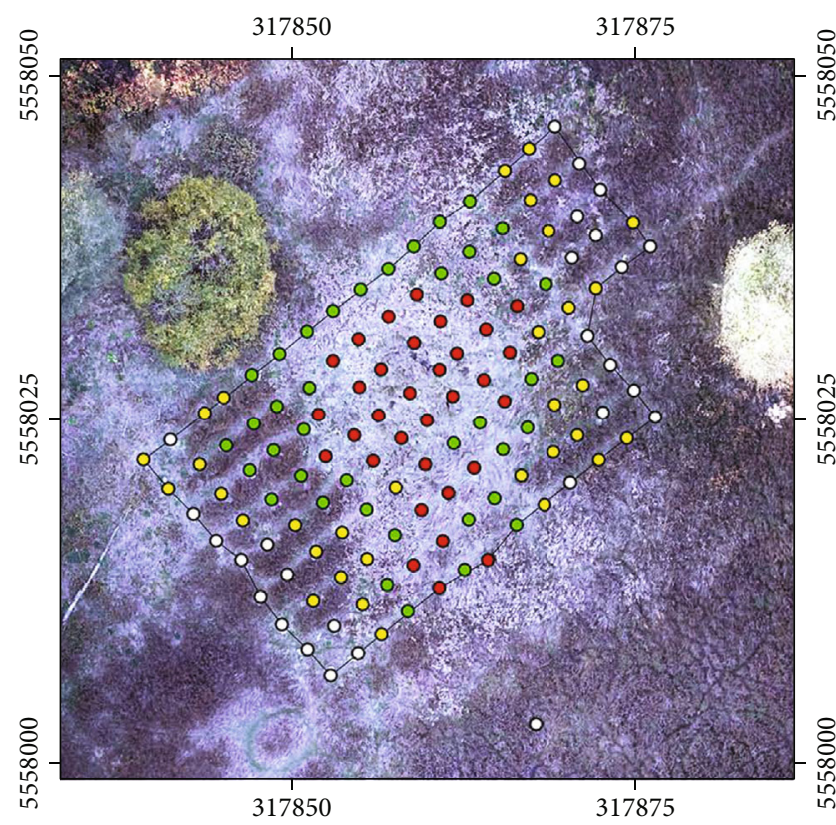

Measurement points

Flux $\left(\mathrm{gm}^{-2} \mathrm{~d}^{-1}\right)$

$0<25$

○ $25-100$

० $100-500$

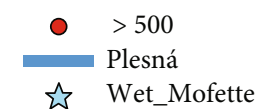

(a)
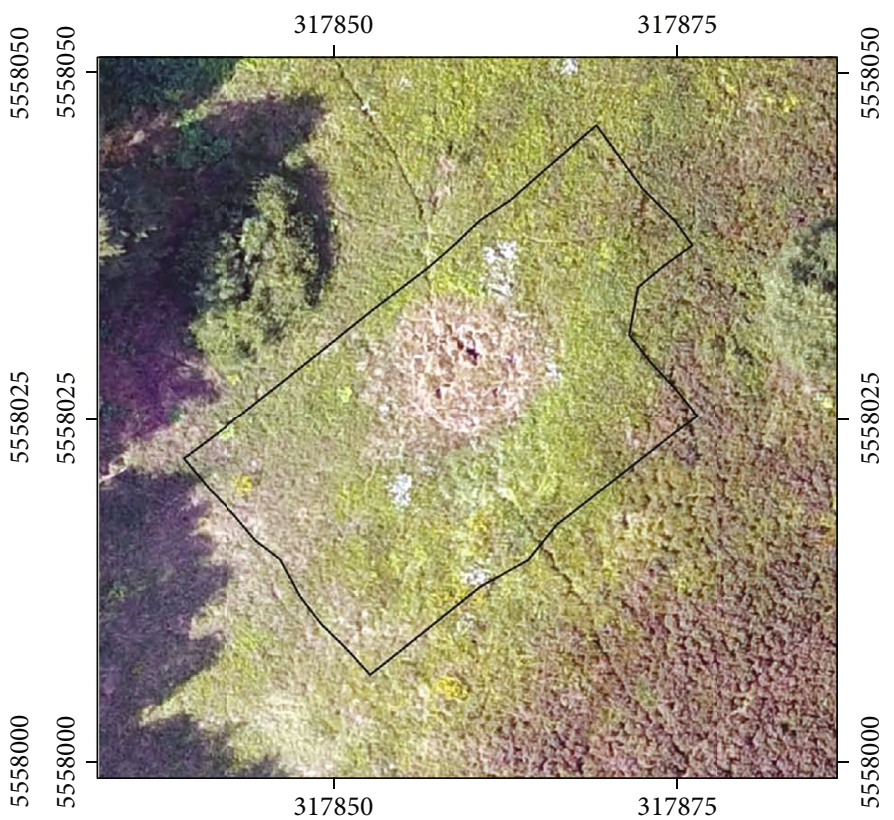

(b)

Figure 6: Continued. 

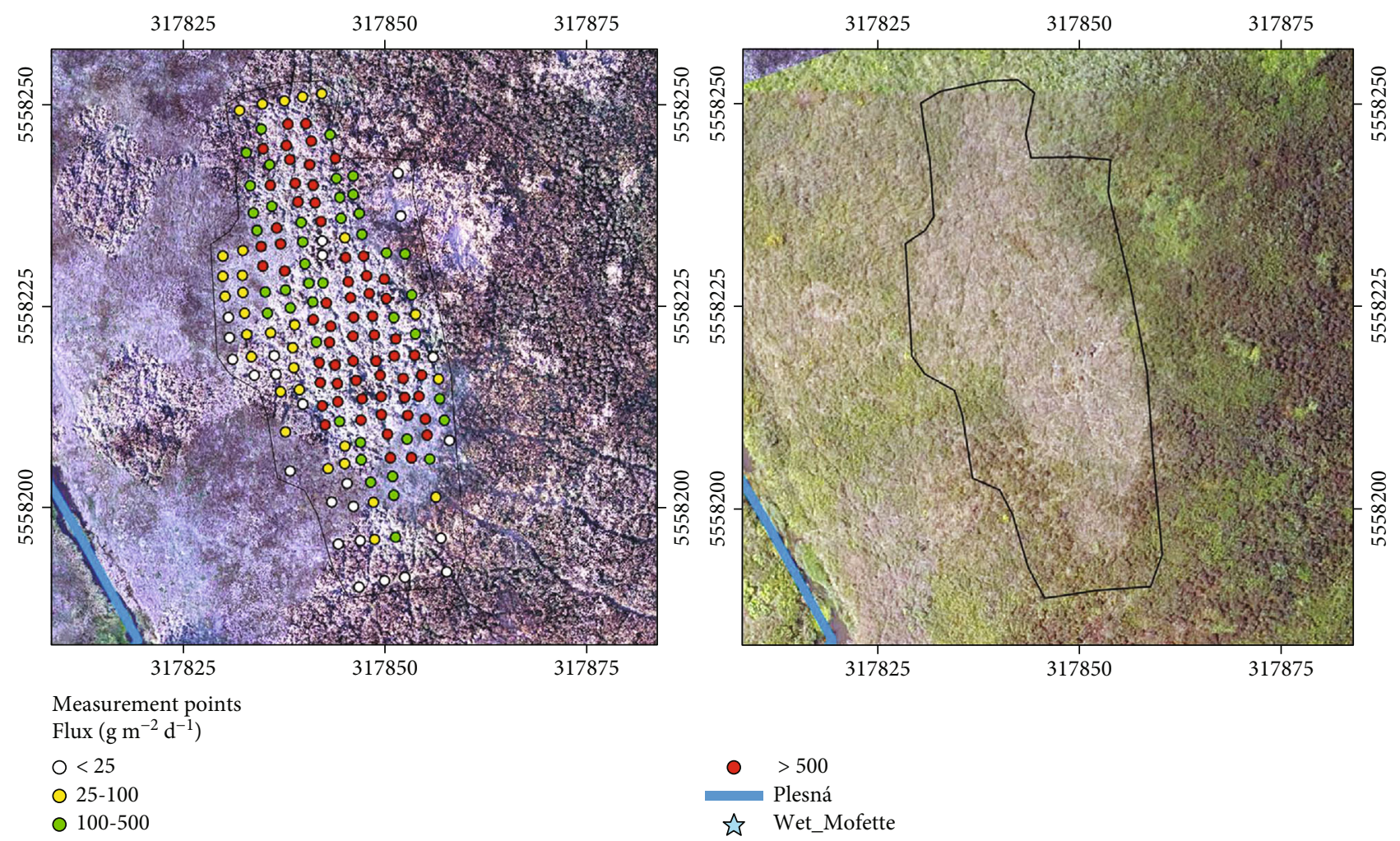

(c)

FIgure 6: Soil $\mathrm{CO}_{2}$ gas flux for (a) MERX, (b) MZ, and (c) MN. Left: October 2018 drone image with partitioned populations. Right: August 2017 drone image.

points were placed in a cross shape with a spacing of $1 \mathrm{~m}$ in the elevated, circular area of which one could not be measured as water started collecting in the hole.

Bublák North 4 by itself is the least prominent anomaly, the maximum of degassing being an order of magnitude lower than the next largest anomaly (Table 6). Nevertheless, it is still visible in the drone images (Figure $7(\mathrm{a})$ ) as an area of brown-colored vegetation exists that is a bit north of the spots with the highest degassing.

$62 \%$ of the analyzed data for all 3 areas of Bublák North belong to population $\mathrm{C}$. The highest measured value is $60.255,82 \mathrm{~g} \mathrm{~m}^{-2} \mathrm{~d}^{-1}$ and the lowest $2,89 \mathrm{~g} \mathrm{~m}^{-2} \mathrm{~d}^{-1}$. In the drone image, due to its size and coloring, BN is easily spotted. BN2 also has an obvious coloring, and BN4 is less visible.

4.2.6. Bublák North-West (BNW). The BNW dry degassing area (Figure 7(b)) was named after the wet mofette Bublák North-West, which is located in the east of that area [17]. Degassing is the highest towards the Plesná and the wet mofette and low in between. The change of color in the vegetation is less obvious in this area compared to other ones, even when looking at the 2017 drone image that is usually better at showing these structures. Figure 7(b) reveals BNW as two separate anomalies of endogenous degassing with a small zone of background degassing in between.

Maximum degassing in this area is $46.386,81 \mathrm{~g} \mathrm{~m}^{-2} \mathrm{~d}^{-1}$ in the anomaly close to the Plesná, with a minimum of $1,35 \mathrm{~g} \mathrm{~m}^{-2} \mathrm{~d}^{-1}$, thus being the area with the lowest maximum.
$36 \%$ of the measured values belong to population C, the smallest share in any of the high degassing areas.

4.2.7. Trees (TR). The trees' area (Figure $7(\mathrm{c})$ ) sits close to a forested area. Due to the shadow in the drone image, the different coloring of the vegetation is hard to see but exists. The 2017 drone image shows areas of brown grass further south of the measured area, which was not possible to see in the field in 2018. The amount of endogenous degassing generally increases with distance to the forested zones. Any further observations on the shape of the degassing zones are hard to make, as not enough points have been placed and measured towards the east.

The highest degassing occurs in the northeast of the area where there are several vegetation-free spots $\left(49.889,41 \mathrm{~g} \mathrm{~m}^{-2} \mathrm{~d}^{-1}\right)$ and is lowest in the forested area with $4,06 \mathrm{~g} \mathrm{~m}^{-2} \mathrm{~d}^{-1} .73 \%$ of the measured points belong to population $\mathrm{C}$.

\section{Discussion}

5.1. Measurement Strategy and Field Locations under Consideration of Mofette Vegetation. The zonation of vegetation in mofette areas can be used as a very important indication to subdivide the areas. According to Figure 8, the mofettophobic zone is located where $\mathrm{CO}_{2}$ gas flux amounts to $<25 \mathrm{~g} \mathrm{~m}^{-2} \mathrm{~d}^{-1}$; the mofettovague zone is defined by $\mathrm{CO}_{2}$ gas fluxes between 25 and $500 \mathrm{~g} \mathrm{~m}^{-2} \mathrm{~d}^{-1}$. Mofettophilic plants grow at $\mathrm{CO}_{2}$ gas fluxes $>500 \mathrm{~g} \mathrm{~m}^{-2} \mathrm{~d}^{-1}$. 

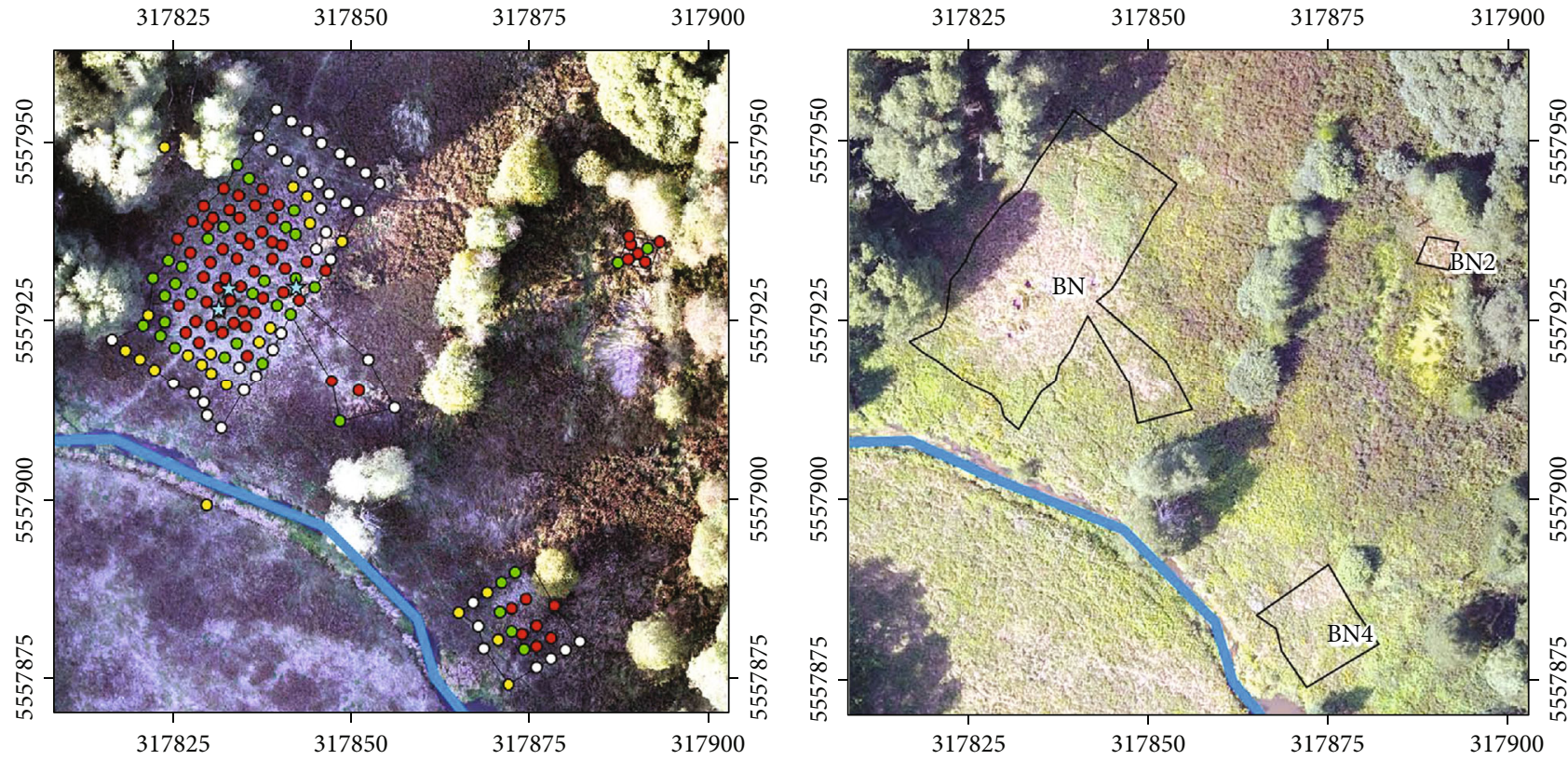

Measurement points

Flux $\left(\mathrm{g} \mathrm{m}^{-2} \mathrm{~d}^{-1}\right)$

O $<25$
O $25-100$
$0.100-500$

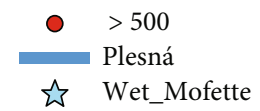

(a)
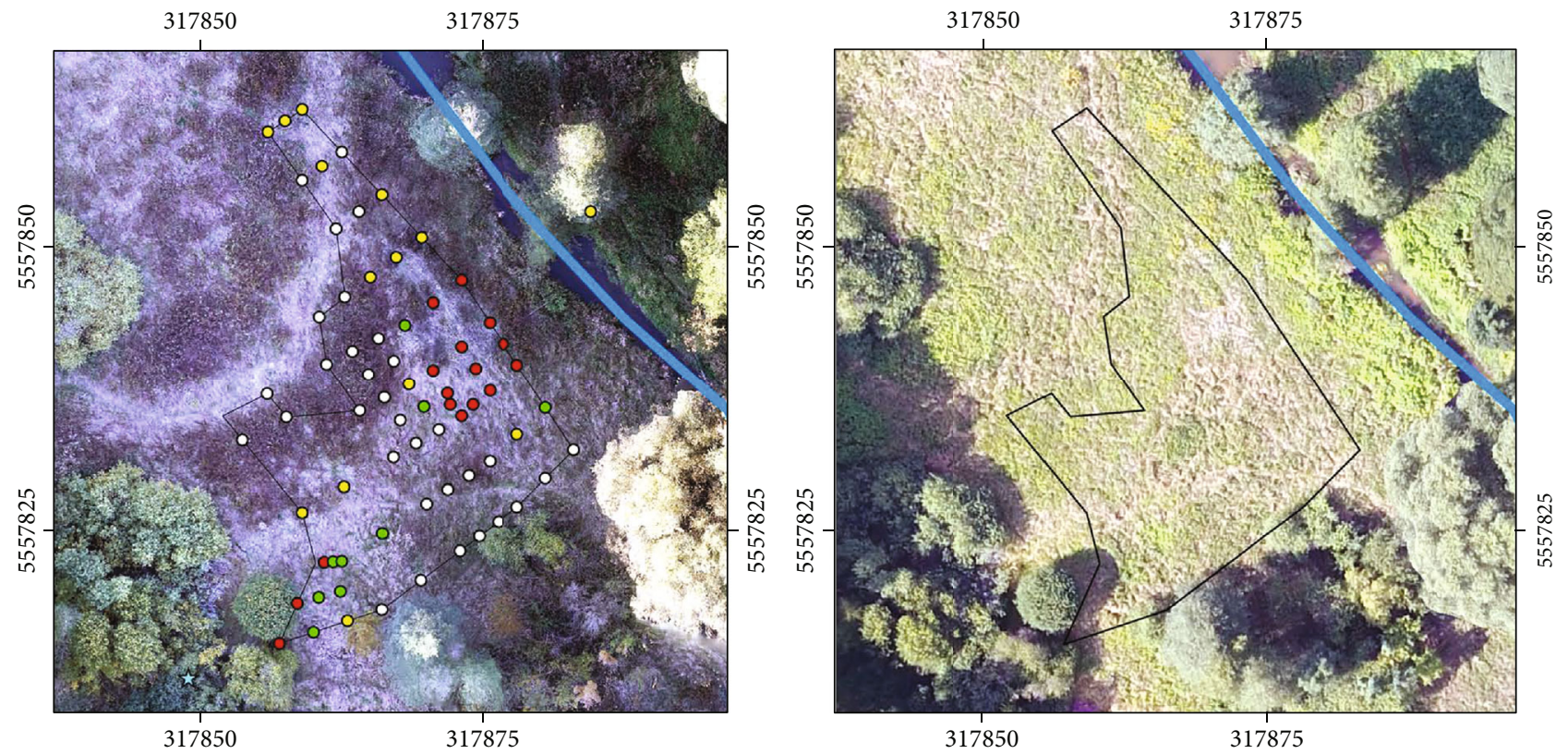

Measurement points

Flux $\left(\mathrm{g} \mathrm{m}^{-2} \mathrm{~d}^{-1}\right)$
$0<25$
○ $25-100$
○ $100-500$

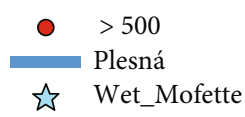

(b)

Figure 7: Continued. 


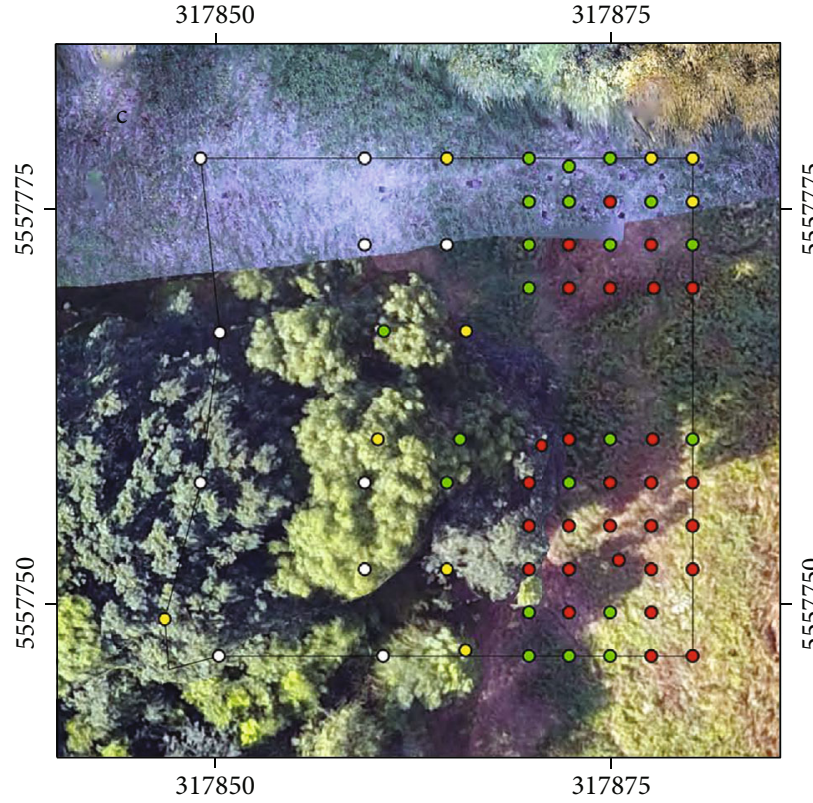

Measurement points

Flux $\left(\mathrm{g} \mathrm{m}^{-2} \mathrm{~d}^{-1}\right)$

$$
\begin{aligned}
& O<25 \\
& \text { O } 25-100 \\
& \text { O } 100-500
\end{aligned}
$$

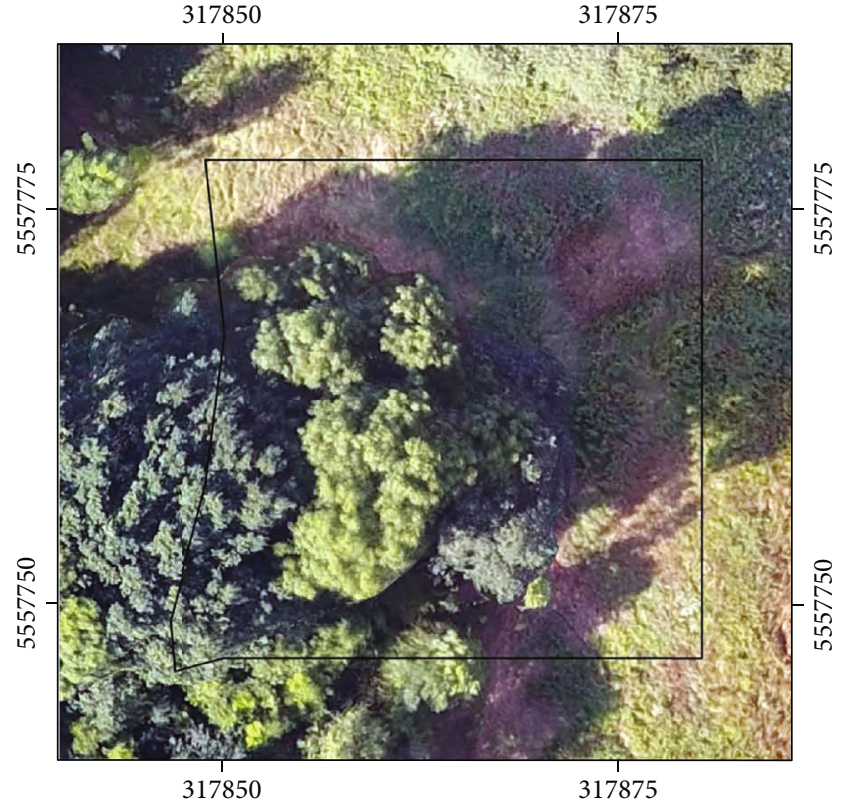

$\circ>500$

¿3 Plesná

(c)

FIGURE 7: Soil $\mathrm{CO}_{2}$ gas flux for (a) BN24, (b) BNW, and (c) TR. Left: October 2018 drone image with partitioned populations. Right: August

\begin{tabular}{|c|c|c|c|c|c|c|}
\hline Area & $\begin{array}{c}\text { Extension } \\
\mathrm{m}^{2}\end{array}$ & $\begin{array}{c}\text { Average flux } \\
\mathrm{g} \mathrm{m}^{-2} \mathrm{~d}^{-1}\end{array}$ & $\begin{array}{c}\text { Median } \\
\mathrm{g} \mathrm{m}^{-2} \mathrm{~d}^{-1}\end{array}$ & $\begin{array}{l}\text { Min. flux } \\
\mathrm{g} \mathrm{m}^{-2} \mathrm{~d}^{-1}\end{array}$ & $\begin{array}{l}\text { Max. flux } \\
\mathrm{g} \mathrm{m}^{-2} \mathrm{~d}^{-1}\end{array}$ & Number of points \\
\hline $50 \mathrm{~m}$ & 432.358 & 27 & 14 & 0,28 & 488,18 & 179 \\
\hline MERX & 1.685 & 5.257 & 326 & 8,43 & $125.773,33$ & 349 \\
\hline $\mathrm{MZ}$ & 703 & 6.092 & 128 & 6,85 & $177.926,17$ & 132 \\
\hline $\mathrm{MN}$ & 1.337 & 3.549 & 261 & 2,29 & $79.591,73$ & 159 \\
\hline BN24 & 979 & 6.632 & 209 & 2,89 & $60.255,82$ & 158 \\
\hline $\mathrm{BNW}$ & 612 & 1.083 & 34 & 1,35 & $46.386,81$ & 71 \\
\hline TR & 985 & 1.634 & 334 & 4,06 & $49.889,41$ & 67 \\
\hline
\end{tabular}
2017 drone image.

TABLE 6: Main parameters of the surveyed areas.

Sassmannshausen [30] mapped BN24 and MERX botanically and specified mofettophobic, mofettovague, and mofettophilic plant communities and demonstrated a correlation between them and the $\mathrm{CO}_{2}$ soil gas concentration in different depths. This work proves, as first in the area, the relationship between vegetation and $\mathrm{CO}_{2}$ gas flux. This is not surprising, as gas concentration and gas flux are mostly related $[17,28]$ but make mapping of $\mathrm{CO}_{2}$ gas flux easier because the point spacing can be adjusted according to plant zonality to the presumed gas flux. Areas with mofettophilic vegetation should, for high accuracy, be measured with a point spacing of $2,5 \mathrm{~m}$. In mofettovague areas, this can be stretched to a distance of $5 \mathrm{~m}$. Mofettophobically marked areas around a mofette can have a spacing of $10 \mathrm{~m}$. Placing at least one row of points around a mofette in the mofettophobic zone would ensure better kriging results.
This relationship is not as clear for BNW, the area with the lowest average degassing and percentage of values in population C except for the $50 \mathrm{~m}$ grid. Neither the 2017 nor the 2018 drone image provides clear information about the location of high degassing. Mapping of gas flux solely based on the vegetation will be difficult in such a case and will certainly lead to oversight of some dry mofettes. Other problems for this approach are agriculturally used areas, as there is no chance for the characteristic vegetation to grow. Botanic zonation could be used for defining a measurement strategy for $\mathrm{CO}_{2}$ gas flux measurements in the highest degassing areas of the agriculturally not used Plesná valley.

5.1.1. GPS Measurements and Drones. The drone images were a great help during the measurements, especially for 


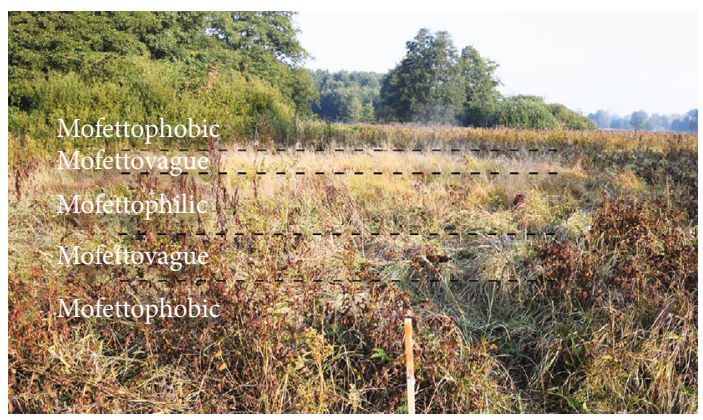

(a)

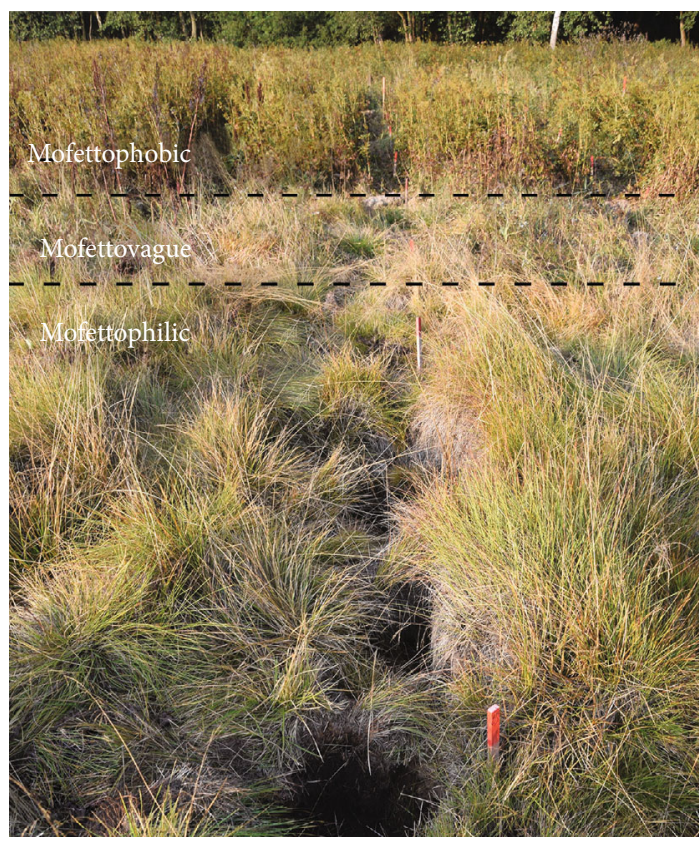

(b)

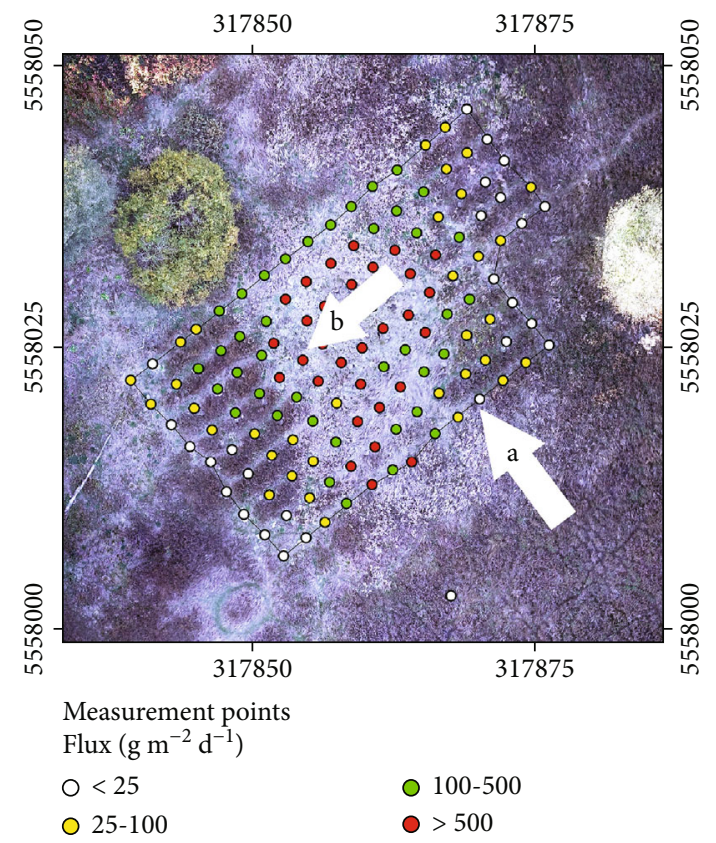

(c)

Figure 8: Mofette vegetation. (a) View of the MZ from the southern edge to the NW. (b) View of the MZ from the center to the SW. (c) Soil $\mathrm{CO}_{2}$ gas flux and location and direction of (a) and (b).

locating the high degassing areas. They allow for a better overview than in the field and are good for verifying the high degassing areas. It is sensible to take the images in spring or early summer as the contrast between the types of vegetation is high (Figures 6 and 7).

The combination of GPS measurements and drone images has been proven to be efficient, accurate, and useful. Measuring every single point would have taken at least 37 hours of pure measurement time. Putting the points with ArcGIS still took around 12 hours but freed up valuable time in the field. This method however requires thorough work in the field as one needs to be sure where each point is. Points covered by foliage need to have their coordinates taken with the GPS. Ideally, points should be left untouched between digging the hole and taking drone pictures so that they do not get buried.

5.1.2. Measurement Grid and Data Analysis. Having a point spacing of $50 \mathrm{~m} \times 50 \mathrm{~m}$ for the overview grid had advantages, but also disadvantages. A grid of this size made it possible to measure the high degassing areas very accurately, which was necessary for the study. However, problems that were encountered during data analysis would not have been as bad, if a $20 \mathrm{~m} \times 20 \mathrm{~m}$ grid would have been used. Finding the correct parameters for transGaussian kriging proved to be difficult due to the poor point distribution (few high distances, many small distances).

This leads to the trans-Gaussian kriging predicting high degassing values for areas that probably do not actually have these as there is no change in vegetation. This problem occurs especially in areas where high degassing values (population C) are on the outer edge of the grid. This is especially striking around BN2 area (Figure 5), where all the measured points have degassing values above $100 \mathrm{~g} \mathrm{~m}^{-2} \mathrm{~d}^{-1}$ which leads to a calculated area of high degassing that is much larger than what would be assumed from observations in the field. On the other hand, this partially outweighs the oversight of potential moderate degassing spots that are not visible on the orthophoto or by vegetation changes. 


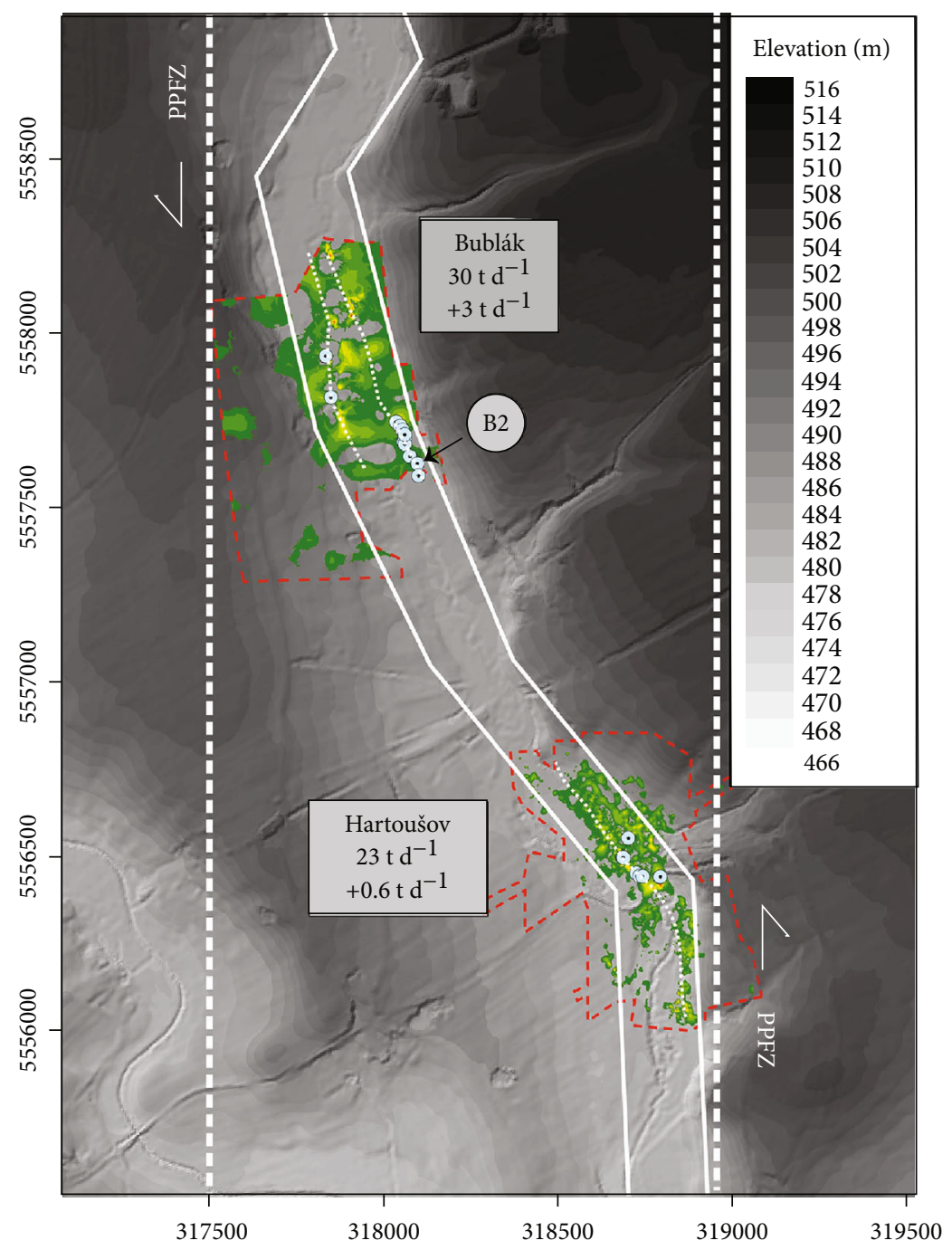

Figure 9: Structural setting of the Hartoušov and Bublák mofette fields with the locations of DDS and wet mofettes (blue dots).

For further measurements, the overview raster should be kept to a point distance of $20 \mathrm{~m} \times 20 \mathrm{~m}$ and areas of highdensity measurements should be around $10 \mathrm{~m}$ larger than the mofettovague zone to avoid problems with data analysis. Alternatively, a small spacing could be kept for the entire BMF zone, which however would not be economical due to the harsh and sturdy vegetation.

5.2. $\mathrm{CO}_{2}$ Degassing at the Poćátky Plesná Fault Zone: Comparison of Bublák and Hartoušov Mofette Fields. In Figure 9, the results from the gas flux measurements of Nickschick et al. [28] which include the results from Kämpf et al. [17] and this study are shown. Overall, 4.647 measurements were carried out in an area of $780.000 \mathrm{~m}^{2}$ between 2009 and 2018 (April-October). The overall degassing for the HMF is likely somewhere between $23 \mathrm{td}^{-1}$ and $97 \mathrm{td}^{-1}$ and for the BMF between $30 \mathrm{td}^{-1}$ and $154 \mathrm{td}^{-1}$ with a respective average of $65,2 \mathrm{~g} \mathrm{~m}^{-2} \mathrm{~d}^{-1}$ and $73 \mathrm{~g} \mathrm{~m}^{-2} \mathrm{~d}^{-1}$ for trans-Gaussian kriging. We favor the values of $30 \mathrm{td}^{-1}$ and $23 \mathrm{td}^{-1}$, as they are the results of the geostatistically most solid estimation. There are N-S, NNW-SSE, and
NW-SE striking degassing elements present in both. Therefore, the two mofette fields are comparable in their $\mathrm{CO}_{2}$ gas flux and tectonics.

From the original interpretation of the fault appearance, some modifications had to be transferred to the location of the PPFZ. Its western part should be moved to the east, to where the N-S striking degassing is located. No changes are necessary for the eastern part.

The distribution of the degassing areas leads to the following two possible interpretations keeping in mind the pull-apart aspect:

(1) There exist two pull-apart basin-like degassing structures as hypothesized in Nickschick et al. [28]. In this case, the wet mofettes in the BMF form the southern basin sidewall fault as the areas with the highest degassing occur north of them. The dry mofettes would form one of the principal displacement zones. This would mean that, to confirm this theory, surveying for dry degassing areas north of the measured area would be needed. 
(2) Contrary to information from Nickschick et al. [28], only one pull-apart basin-like degassing structure exists. The HMF and BMF would be part of the northern or southern basin sidewall of a pull-apart basin.

The second theory seems to fit the observations better, as the length to width ratio of such a basin could be around 3:1 with an acute angle of around $30^{\circ}$, as most of the earths pull-apart structures do. In Nickschick et al. [28] and the first theory, this is not kept in mind as the suggested pull-apart basins are not long enough. However, both theories have the problem that, except for the river valley, there is no explicitly depressive topography and the sediment thickness is less in the center of the suggested pull-apart basin than in the margin ([28], Figure 9). This is contrary to what would be expected [34]. Yuce at al. [34] also located the zones of the highest degassing rates at the basin sidewalls. The Bublák dry degassing areas do not follow this direction, but rather the direction of what would be a principal displacement zone, which is also the case for some of the data from Nickschick et al. [28].

A more plausible theory might be that there exists a pattern of en-echelon faults that show the earliest stages of faulting [46] with the active fault segments oriented in N-S (Figure 9). This is in accordance with tectonic interpretation of the PPFZ shear zone fault segments [15, 47], seismological results according to Vavryčuk [16], and reflection seismic evidence of tectonic activity of the PPFZ by Halpaap et al. [48]. Bankwitz et al. [15] pointed out that the surface of the PPFZ corresponds to an about $1 \mathrm{~km}$ wide sinistral shear zone consisting of short NNE and NNW striking segments in $\mathrm{km}$ scale. The zigzag course of the Plesna river is related to these segments, interpreted as sinistral P- $(=\mathrm{NNE})$ and sinistral Riedel shears (=NNW) inside of the PPFZ. Peterek et al. [47] detected displacement (significant uplift of the eastern flanks of the PPFZ) of age-different river terraces of the Ohře (Eger) river valley at the area where the valley is crossing the PPFZ as evidence of the tectonic activity of the PPFZ from Mid Pleistocene up to Holocene. Inside the PPFZ, Halpaap et al. [48] detected the complete absence of faulting in the sediment strata; meanwhile, the crystalline basement is strongly faulted. We interpreted the degassing structures at the BMF and HMF according to our own results and literature data as pattern of en-echelon faults that show reactivation of preexisting faults at the earliest stages of faulting (Figure 9).

\section{Conclusions and Outlook}

This study presents the results of $\mathrm{CO}_{2}$ gas flux measurements of a cold mantle-derived $\mathrm{CO}_{2}$ release in the western Eger Rift, geodynamically most active area of the European Cenozoic Rift System [8].

The $\mathrm{CO}_{2}$ gas flux measurements yielded various results:

(i) The experiments carried out here continue gas flux measurements of the Hartoušov mofette field [17, 28], located $1 \mathrm{~km}$ south of the working area. As a new technique, drone-based orthophotos were used in combination with knowledge of plant zonation in $\mathrm{CO}_{2}$ mofette fields. For cases where only rough knowledge of the gas flux is necessary, mapping the vegetation can suffice. This, however, is only reliable for areas with high degassing averages that are not agriculturally used.

(ii) Mofette vegetation can be used as a guide for a reasonable grid spacing, ranging from $2,5 \mathrm{~m}$ in mofettophilic areas to $10 \mathrm{~m}$ in mofettophobic areas around a dry mofette. For data analysis, a point spacing of $50 \mathrm{~m}$ was proved to be problematic. Better results can be achieved by smaller grids, for example, $20 \mathrm{~m}$ point spacing as in Nickschick et al. [28].

(iii) The average, by trans-Gaussian kriging-calculated degassing for the BMF, is $30 \mathrm{td}^{-1}$ for an area of $0,43 \mathrm{~km}^{2}$. For the HMF, it is $23 \mathrm{td}^{-1}$ for an area of $0,35 \mathrm{~km}^{2}$. The average degassing values are in the same magnitude of order and show that the two areas are comparable.

(iv) The hypothesis of pull-apart basins from Nickschick et al. [28] was tested. During the interpretation of the data and using new results from Kämpf et al. [17] and Nickschick et al. [28], it was found that the degassing in the BMF is not in accordance with this interpretation, based on the direction of degassing as well as topography and sediment fill of the suggested basins. Emanate from our own results and literature data, a new model was proposed in which enechelon faults show beginning faulting while reactivating preexisting faults. The en-echelon faults inside of the PPFZ act as fluid channels to depth $\left(\mathrm{CO}_{2}\right.$ conduits $)$.

\section{Data Availability}

All the data of the manuscript are included in the tables.

\section{Conflicts of Interest}

The authors declare that the research was conducted in the absence of any commercial or financial relationships that could be construed as a potential conflict of interest.

\section{Acknowledgments}

We would like to express our gratitude to the German Research Foundation (DFG) for funding this project (KA902/9, 16). The extensive fieldwork in 2017 and 2018 was funded by the expedition funds "ICDP-Eger" of the Helmholtz-Zentrum Potsdam - Deutsches GeoForschungsZentrum GFZ. We thank M. Bogdanowitsch and S. Kraus for their scientific contributions during fieldwork. The authors thank Frank Kreienkamp, German Weather Service for the thermopluviogram of the Free State of Saxony. We are grateful to Karin Bräuer (UFZ-Helmholtz Centre for Environmental Research, Germany) for the critical review of the final version of the manuscript. 


\section{References}

[1] C. Prodehl, S. Müller, and V. Haak, "The European Cenozoic rift system," in Continental Rifts: Evolution, Structure, Tectonics, Developments in Geotectonics, K. H. Olsen, Ed., vol. 25, pp. 133-212, Elsevier, New York, 1995.

[2] J. Ulrych, J. Dostal, J. Adamovič et al., "Recurrent Cenozoic volcanic activity in the Bohemian Massif (Czech Republic)," Lithos, vol. 123, no. 1-4, pp. 133-144, 2011.

[3] P. Štěpančíková, T. Fischer, J. Stemberk jr., L. Nováková, F. Hartvich, and P. M. Figueiredo, "Active tectonics in the Cheb Basin: youngest documented Holocene surface faulting in Central Europe?," Geomorphology, vol. 327, pp. 472-488, 2019.

[4] P. Rojik, O. Fejfar, J. Dašková et al., "Krušné hory Piedmont basins - Cheb basin," in Tertiary Basins and Lignite Deposits of the Czech Republic, J. Pešek, Ed., pp. 143-161, Czech Geological Survey, Prague, 2014.

[5] H. Credner, "Das vogtländisch-erzgebirgische Erdbeben vom 23. November 1875," Zeitschrift für die Gesammten Naturwissenschaften, vol. 48, pp. 246-269, 1876.

[6] J. Horalek and T. Fischer, "Role of crustal fluids in triggering the West Bohemia/Vogtland earthquake swarms: just what we know (a review)," Studia Geophysica et Geodaetica, vol. 52, no. 4, pp. 455-478, 2008.

[7] K. Bräuer, H. Kämpf, G. Strauch, and S. M. Weise, "Isotopic evidence $\left({ }^{3} \mathrm{He} /{ }^{4} \mathrm{He},{ }^{13} \mathrm{C}_{\mathrm{CO} 2}\right)$ of fluid-triggered intraplate seismicity," Journal of Geophysical Research: Solid Earth, vol. 108, no. B2, 2003.

[8] K. Bräuer, H. Kämpf, S. Niedermann, G. Strauch, and J. TesařNatural laboratory NW Bohemia: Comprehensive fluid studies between 1992 and 2005 used to trace geodynamic processes," Geochemistry, Geophysics, Geosystems, vol. 9, no. 4, 2008.

[9] S. Brune, S. E. Williams, and R. D. Müller, "Potential links between continental rifting, $\mathrm{CO}_{2}$ degassing and climate change through time," Nature Geoscience, vol. 10, no. 12, pp. 941-946, 2017.

[10] J. Horálek and T. Fischer, "Intraplate earthquake swarms in West Bohemia/Vogtland (Central Europe)," JÖKULL, vol. 60, pp. 67-87, 2010.

[11] M. Ibs-von Seht, T. Plenefisch, and K. Klinge, "Earthquake swarms in continental rifts - A comparison of selected cases in America, Africa and Europe," Tectonophysics, vol. 452, no. 1-4, pp. 66-77, 2008.

[12] J. Mrlina, H. Kämpf, C. Kroner et al., "Discovery of the first Quaternary maar in the Bohemian Massif, Central Europe, based on combined geophysical and geological surveys," Journal of Volcanology and Geothermal Research, vol. 182, no. 1-2, pp. 97-112, 2009.

[13] J. Rohrmüller, H. Kämpf, E. Geiß et al., "Reconnaissance study of an inferred Quaternary maar structure in the western part of the Bohemian Massif near Neualbenreuth, NEBavaria (Germany)," International Journal of Earth Sciences, vol. 107, no. 4, pp. 1381-1405, 2018.

[14] T. Fischer, J. Horálek, P. Hrubcová, V. Vavryčuk, K. Bräuer, and H. Kämpf, "Intra-continental earthquake swarms in West-Bohemia and Vogtland: a review," Tectonophysics, vol. 611, pp. 1-27, 2014.

[15] P. Bankwitz, G. Schneider, H. Kämpf, and E. Bankwitz, "Structural characteristics of epicentral areas in Central Europe: study case Cheb Basin (Czech Republic)," Journal of Geodynamics, vol. 35, no. 1-2, pp. 5-32, 2003.
[16] V. Vavryčuk, "Principal earthquakes: theory and observations from the 2008 West Bohemia swarm," Earth and Planetary Science Letters, vol. 305, no. 3-4, pp. 290-296, 2011.

[17] H. Kämpf, K. Bräuer, J. Schumann, K. Hahne, and G. Strauch, " $\mathrm{CO}_{2}$ discharge in an active, non-volcanic continental rift area (Czech Republic): Characterisation $\left(\delta^{13} \mathrm{C}\right.$, $\left.{ }^{3} \mathrm{He} /{ }^{4} \mathrm{He}\right)$ and quantification of diffuse and vent $\mathrm{CO}_{2}$ emissions," Chemical Geology, vol. 339, pp. 71-83, 2013.

[18] T. Nickschick, C. Flechsig, J. Mrlina, F. Oppermann, F. Löbig, and T. Günther, "Large-scale electrical resistivity tomography in the Cheb Basin (Eger Rift) at an ICDP monitoring drill site to image fluid-related structures," Solid Earth Discussions, pp. $1-29,2019$, in review.

[19] K. Bräuer, H. Kämpf, S. Niedermann, and G. Strauch, "Monitoring of helium and carbon isotopes in the western Eger Rift area (Czech Republic): relationships with the 2014 seismic activity and indications for recent (2000-2016) magmatic unrest," Chemical Geology, vol. 482, pp. 131145, 2018.

[20] W. H. Geissler, H. Kämpf, R. Kind et al., "Seismic structure and location of $\mathrm{C} \mathrm{CO}_{2}$ source in the upper mantle of the western Eger (Ohře) Rift, central Europe," Tectonics, vol. 24, no. 5, 2005.

[21] H. Kämpf, W. H. Geissler, and K. Bräuer, "Combined Gasgeochemical and Receiver Function Studies of the Vogtland/NW Bohemia Intraplate Mantle Degassing Field, Central Europe," in Mantle Plumes, J. R. R. Ritter and U. R. Christensen, Eds., pp. 127-158, Springer, Berlin, Heidelberg, 2007.

[22] F. H. Weinlich, K. Bräuer, H. Kämpf, G. Strauch, J. Tesař, and S. M. Weise, "An active subcontinental mantle volatile system in the western Eger rift, Central Europe: gas flux, isotopic (He, C, and N) and compositional fingerprints," Geochimica et Cosmochimica Acta, vol. 63, no. 21, pp. 3653-3671, 1999.

[23] F. H. Weinlich, J. Tesař, S. M. Weise, K. Bräuer, and H. Kämpf, "Gas flux distribution in mineral springs and tectonic structure in the western Eger Rift," Journal of the Czech Geological Society, vol. 43, pp. 91-110, 1998.

[24] R. Bussert, H. Kämpf, C. Flechsig et al., "Drilling into an active mofette: pilot-hole study of the impact of $\mathrm{CO}_{2}$-rich mantle-derived fluids on the geo-bio interaction in the western Eger Rift (Czech Republic)," Scientific Drilling, vol. 23, pp. 13-27, 2017.

[25] E. H. Flores, J. Umlauft, A. Schmidt, and M. Korn, "Locating mofettes using seismic noise records from small dense arrays and matched field processing analysis in the NW Bohemia/Vogtland Region, Czech Republic," Near Surface Geophysics, vol. 14, pp. 327-335, 2016.

[26] K. Bräuer, H. Kämpf, and G. Strauch, "Earthquake swarms in non-volcanic regions: what fluids have to say," Geophysical Research Letters, vol. 36, no. 17, 2009.

[27] K. Bräuer, H. Kämpf, U. Koch, and G. Strauch, "Monthly monitoring of gas and isotope compositions in the free gas phase at degassing locations close to the Nový Kostel focal zone in the western Eger Rift, Czech Republic," Chemical Geology, vol. 290, no. 3-4, pp. 163-176, 2011.

[28] T. Nickschick, H. Kämpf, C. Flechsig, J. Mrlina, and J. Heinicke, " $\mathrm{CO}_{2}$ degassing in the Hartoušov mofette area, western Eger Rift, imaged by $\mathrm{CO}_{2}$ mapping and geoelectrical and gravity surveys," International Journal of Earth Sciences, vol. 104, no. 8, pp. 2107-2129, 2015.

[29] T. Rennert and H. Pfanz, "Hypoxic and acidic - soils on mofette fields," Geoderma, vol. 280, pp. 73-81, 2016. 
[30] F. Sassmannshausen, "Vegetationsökologische Charakterisierung terrestrischer Mofettenstandorte am Beispiel des westtschechischen Plesná-Tals," Ph.D. thesis, University of Duisburg - Essen, German, 2010.

[31] H. Pfanz, Kalter Atem Schlafender Vulkane, RVDL-Verlag, Köln, 2008, in German.

[32] H. Pfanz, G. Yüce, A. H. Gulbay, and A. Gokgoz, "Deadly $\mathrm{CO}_{2}$ gases in the Plutonium of Hierapolis (Denizli, Turkey)," Archaeological and Anthropological Sciences, vol. 11, no. 4, pp. 1359-1371, 2019.

[33] A. Aydin and A. Nur, "Evolution of pull-apart basins and their scale independence," Tectonics, vol. 1, no. 1, pp. 91-105, 1982.

[34] G. Yuce, C. C. Fu, W. D'Alessandro et al., "Geochemical characteristics of soil radon and carbon dioxide within the Dead Sea Fault and Karasu Fault in the Amik Basin (Hatay), Turkey," Chemical Geology, vol. 469, pp. 129-146, 2017.

[35] C. Flechsig, J. Heinicke, J. Mrlina et al., "Integrated geophysical and geological methods to investigate the inner and outer structures of the Quaternary Mýtina maar (WBohemia, Czech Republic)," International Journal of Earth Sciences, vol. 104, no. 8, pp. 2087-2105, 2015.

[36] West Systems, "Portable diffuse flux meter with LI-COR $\mathrm{CO}_{2}$ detector handbook," Release, vol. 8, p. 2, 2012.

[37] G. Chiodini, R. Cioni, M. Guidi, B. Raco, and L. Marini, "Soil $\mathrm{CO}_{2}$ flux measurements in volcanic and geothermal areas," Applied Geochemistry, vol. 13, no. 5, pp. 543-552, 1998.

[38] M. E. Hinkle, "Environmental conditions affecting concentrations of $\mathrm{He}, \mathrm{CO}_{2}, \mathrm{O}_{2}$ and $\mathrm{N}_{2}$ in soil gases," Applied Geochemistry, vol. 9, no. 1, pp. 53-63, 1994.

[39] C. Flechsig, R. Bussert, J. Rechner, C. Schütze, and H. Kämpf, "The Hartušov Mofette field in the Cheb Basin, Western Eger Rift (Czech Republic): a comparative geoelectric, sedimentologic and soil gas study of a magmatic diffuse $\mathrm{CO}_{2}$-degassing structure," Zeitschrift für Geologische Wissenschaften, vol. 36, pp. 177-193, 2008.

[40] R. O. Gilbert, Statistical Methods for Environmental Pollution Monitoring, Wiley, New York, 1987.

[41] J. L. Lewicki, D. Bergfeld, C. Cardellini et al., "Comparative soil $\mathrm{CO}_{2}$ flux measurements and geostatistical estimation methods on Masaya volcano, Nicaragua," Bulletin of Volcanology, vol. 68, no. 1, pp. 76-90, 2005.

[42] N. Cressie, "Spatial prediction and ordinary kriging," Mathematical Geology, vol. 20, no. 4, pp. 405-421, 1988.

[43] G. E. P. Box and D. R. Cox, "An analysis of transformations," Journal of the Royal Statistical Society: Series B (Methodological), vol. 26, no. 2, pp. 211-243, 1964.

[44] T. Rennert, K. Eusterhues, V. de Andrade, and K. U. Totsche, "Iron species in soils on a mofette site studied by Fe K-edge X-ray absorption near-edge spectroscopy," Chemical Geology, vol. 332-333, pp. 116-123, 2012.

[45] G. Chiodini, C. Cardellini, M. C. Lamberti et al., "Carbon dioxide diffuse emission and thermal energy release from hydrothermal systems at Copahue-Caviahue Volcanic Complex (Argentina)," Journal of Volcanology and Geothermal Research, vol. 304, pp. 294-303, 2015.

[46] J. D. Muirhead and S. A. Kattenhorn, "Activation of preexisting transverse structures in an evolving magmatic rift in East Africa," Journal of Structural Geology, vol. 106, pp. 118, 2018.
[47] A. Peterek, C.-D. Reuther, and R. Schunk, "Neotectonic evolution of the Cheb Basin (Northwestern Bohemia, Czech Republic) and its implications for the late Pliocene to recent crustal deformation in the western part of the Eger Rift," Zeitschrift für Geologische Wissenschaften, vol. 39, pp. 335-365, 2011.

[48] F. Halpaap, M. Paschke, and F. Bleibinhaus, "Shallow reflection seismic evidence of tectonic activity in the Cheb Basin, NW Bohemia," Studia Geophysica et Geodaetica, vol. 62, no. 1, pp. 80-101, 2018. 

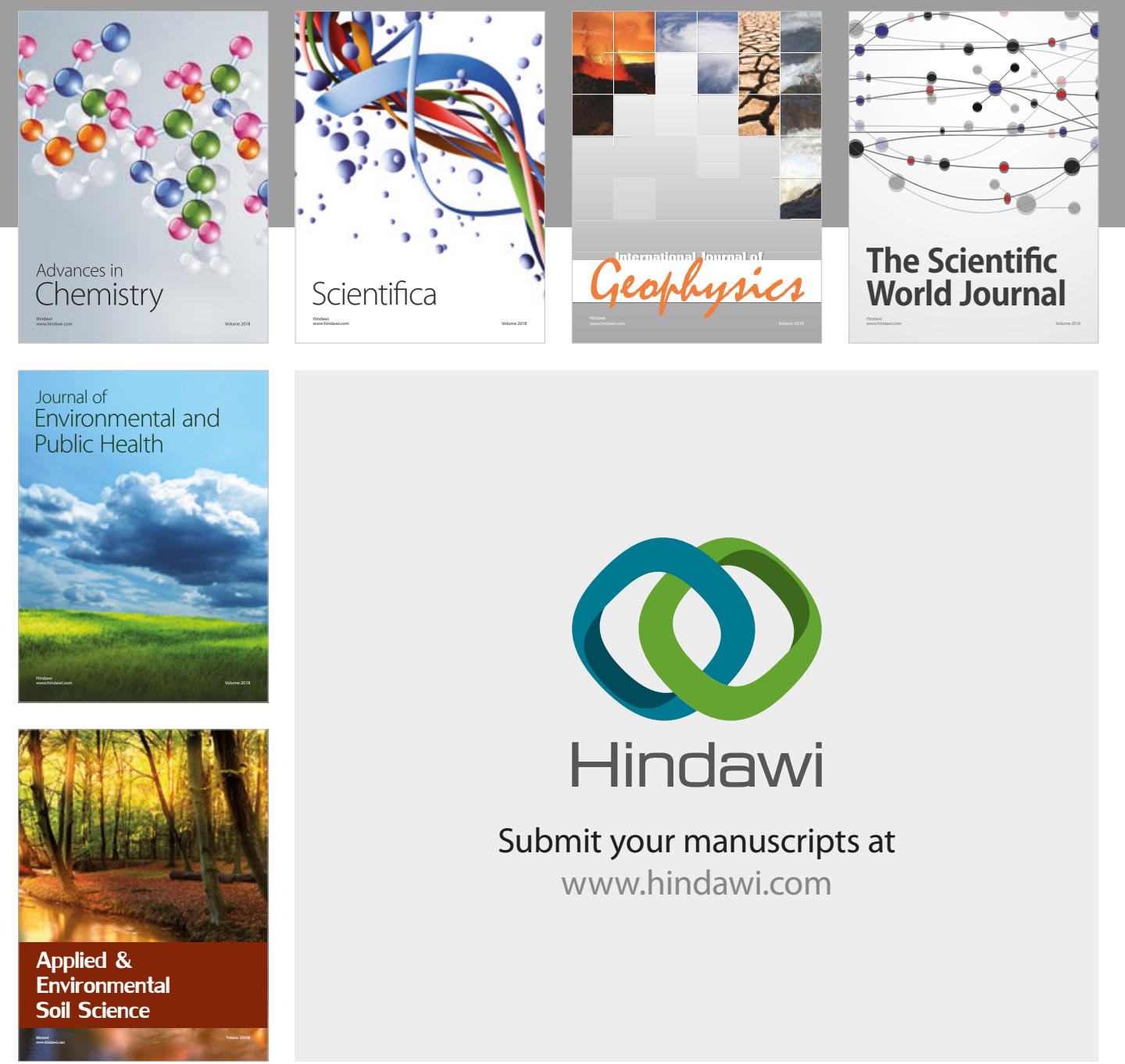

The Scientific

\section{World Journal}
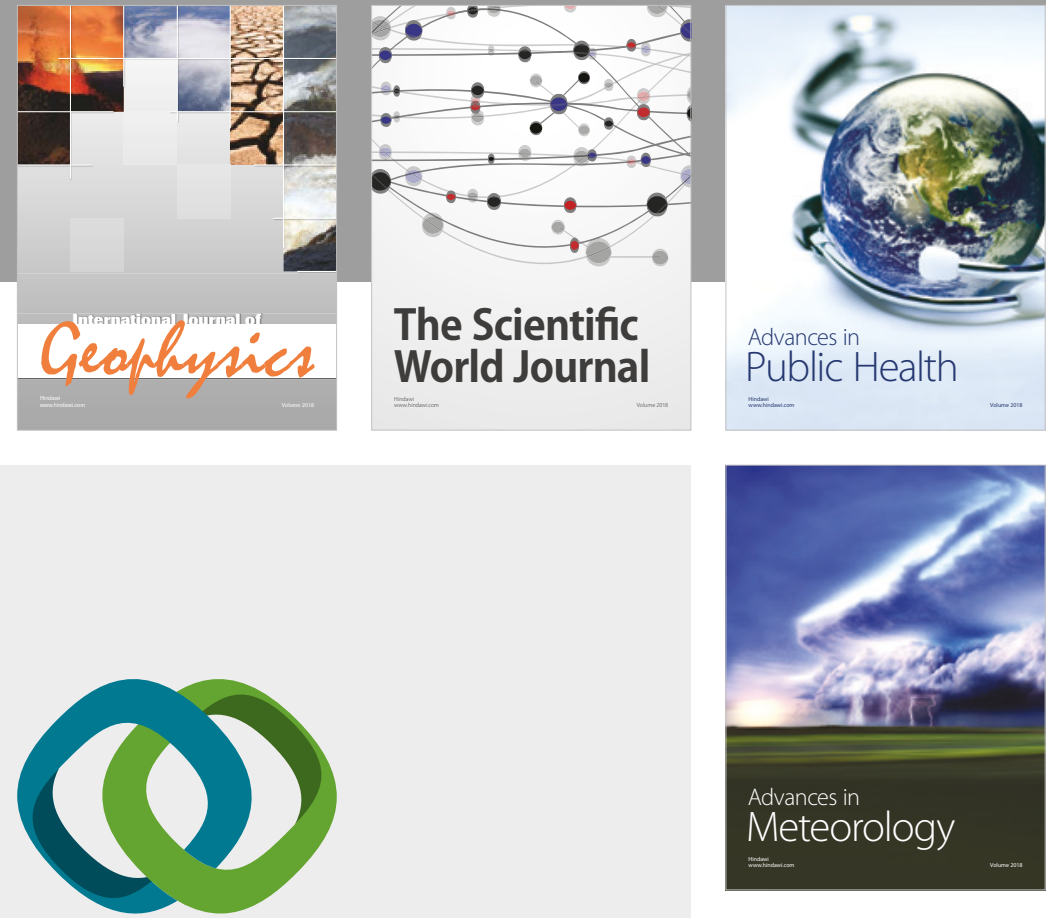

Advan

Public Health

\section{Hindawi}

Submit your manuscripts at

www.hindawi.com
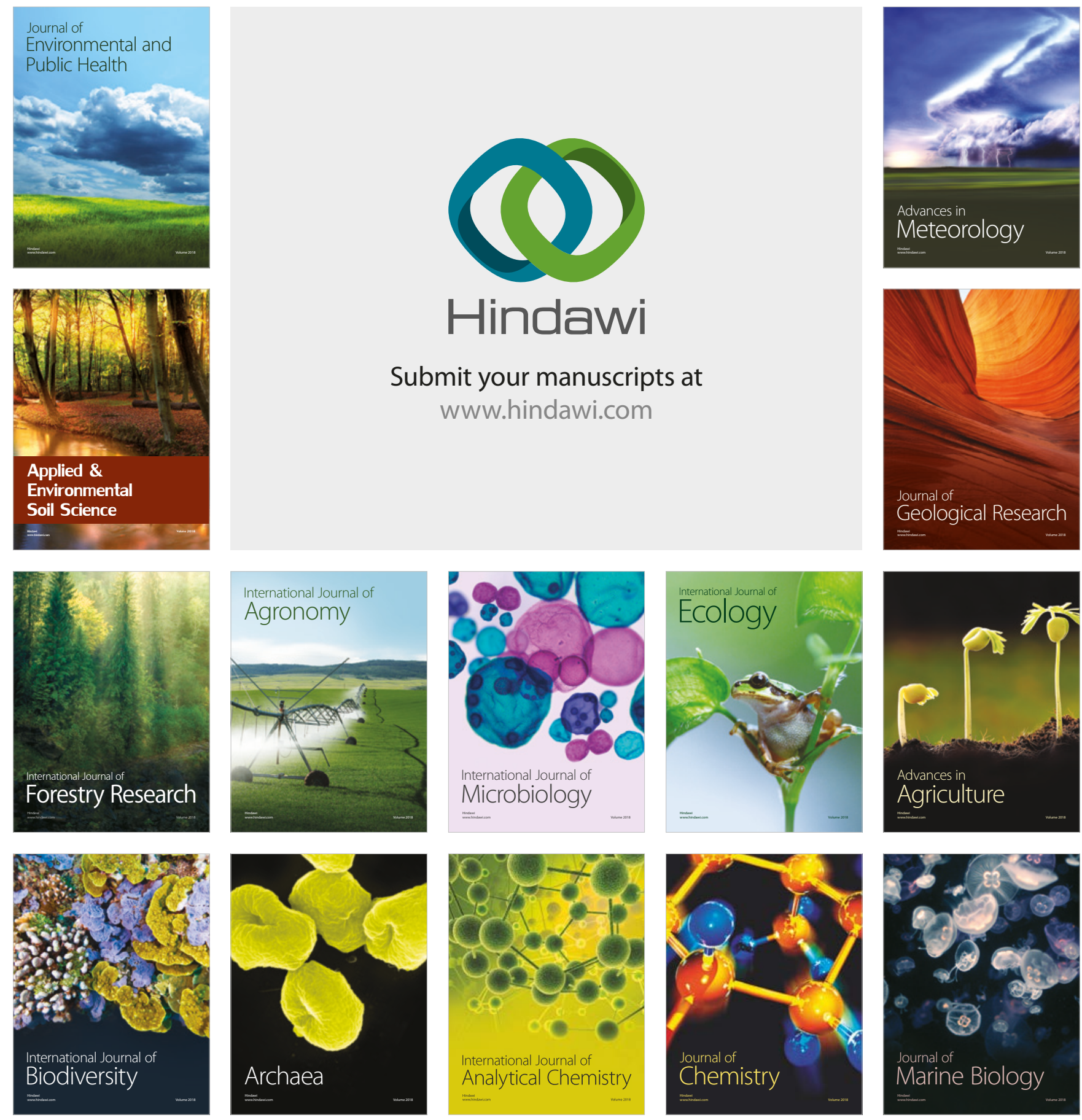